\title{
Preparation and Reactivity of Polyfunctional Zinc and Copper Organometallics Bearing Sulfur Functionalities
}

\author{
S. Achyutha Rao, Tso-Sheng Chou, Ioana Schipor and Paul Knochel* \\ The Willard H. Dow Laboratories, Deparment of Cherristry \\ The University of Michigan \\ Ann Arbor, Michigan 48109
}

(Received in USA 1 October 1991)

Key Words: zinc and copper organometallics, thicethers, thioesters, sulfones

\begin{abstract}
THF under very mild conditions (10-25 $\left.{ }^{\circ}, 0,5-2 \mathrm{~h}\right)$ leading to ainc a-thioorganometallics. After a transwetallation with $\mathrm{CuCN} 2 \mathrm{LCCl}$, the corresponding copper reagents 8 and 7 reacted with various electrophiles $(1$-haloalkynes, aldehydes, enones, acyl chlorides, altylic halides. trialkyltin halides) affording polyfunctional thioesters and sulfides of type 9 or 10 in excellent yields. Of special interest is that, contrary to lithium $\alpha$-thiocarbanions, these zinc-copper reagents can bear uarious functional groups like esters or nimiles. The same approach allowed the preparation of various $\gamma$ thio-substituted zinc and copper reagents bearing phenylthio, phenylsulfinyl, or $\alpha$-(phenylsulfonyl)vinyl functionalities (20-22) which also display a good ability to form new carbon-carbon bonds.
\end{abstract}

The development of many new synthetic methods using main group organometallics was stimulated by the applications of sulfur stabilized lithium organomesallics in organic chemistry. ${ }^{1}$ in this paper we wish to report the preparation of the first polyfunctional zinc and copper organometallic compounds bearing sulfur functionalities in the alpha or gamma position to the carbon-metal bond as well as their reactivity toward typical organic electrophiles. In a preliminary report $^{2}$ we showed that a phenylthio group (PhS) and a phenylsulfinyl group (PhS(O)) were tolerated in the zinc insertion forming organometallics such as 1 and 2.

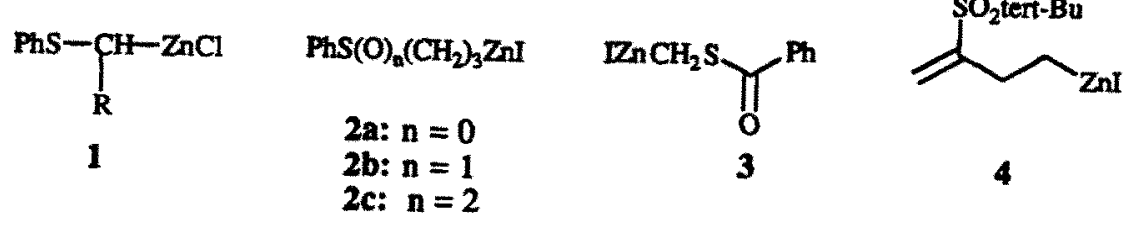

Herein, we extended our previous study and found that a thioester function ( $\mathrm{SCOPh}$ ) or an unsanurated sulfone functionality $\left(\mathrm{H}_{2} \mathrm{C}=\mathrm{C}\left(\mathrm{SO}_{2} \mathrm{t}-\mathrm{Bu}\right)\right.$ ) can also be present during the formation and subsequent reactions of a zinc organometallic such as 3 or 4 . Compared to the more classical lithium $\alpha$-thiocarbanions, the organozinc derivatives $1-4$ tolerate the presence of functional groups like an ester or nitrile. After their transmetallation to the corresponding copper compounds, they were found to react in high yields with various classes of electrophiles such as enones, allylic bromides, aldehydes, acid chlorides and alkynyl bromides. 


\section{RESULTS AND DISCUSSION}

Whereas a primary alkyl iodide requires a temperature of $40-45^{\circ} \mathrm{C}$ to be converted to the corresponding alkylzinc iodide, the presence of a heteroatom in close proximity to the carbon-iodine bond greatly facilitates the organozinc formation. Thus, iodomethyl pivalate ( $\mathrm{ICH}_{2} \mathrm{OCOtert-Bu}$ ) can be transformed into pivaloyloxymethylzinc iodide ( $\left.\mathrm{ZnCH}_{2} \mathrm{OCOtert-Bu}\right)$ within $1 \mathrm{~h}$ at $12-13{ }^{\circ} \mathrm{C}$ in THF. ${ }^{3}$ An even stronger acceleration was observed in the case of iodomethylthiobenzoate 5 which forms the zinc derivative 3 at $8^{\circ} \mathrm{C}$ in less than an hour (Scheme D. Usually unactivated zinc dust does not insert into carbon-chlorine bonds in THF solution and rarely into carbon-bromine bonds. 5 However, the phenylthio group of $\alpha$-chloroalkyl phenyl sulfides 6 of type 6 facilitates the zinc insertion to such an extent that these substrates can be con verted to $\alpha$-phenylthioalkylzinc chlorides 1 in THF at $25^{\circ} \mathrm{C}$ in $2 \mathrm{~h}$ in over $85 \%$ yield (Scheme 1 ).

Scheme I<smiles>CCSC(=O)c1ccccc1</smiles>

5<smiles>[R]C(Cl)[SnH3]</smiles>

6

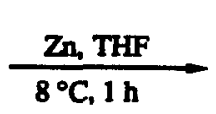

$8^{\circ} \mathrm{C}, 1 \mathrm{~h}$

$\underset{\mathrm{Zn}, \text { THF }}{25^{\circ} \mathrm{C}, 2 \mathrm{~h}}$<smiles>O=C(SC[Tl])c1ccccc1</smiles>

3

( $>80 \%$ yield)<smiles></smiles>

( $>85 \%$ yield)

In strong contrast, it was found that $\alpha$-chloroalkyl alkyl sulfides such as chloromethyl methyl sulfide do not insert zinc under these reaction conditions. Interestingly, the thioester function present in 5 is tolerated in the organozinc formation.7 Furthermore, the chlorides 6 can contain a cyano or an ester functional group, allowing the first preparation of highly functionalized $\alpha$-thiocarbanions. The organometallics 1 and 3 are unreactive toward most classes of organic electrophiles. However, transmetallation to the corresponding copper derivatives 7 and 8 respectively, using the THF soluble copper salt $\mathrm{CuCN} \cdot 2 \mathrm{LiCl}^{8}$, affords reagents that react with various electrophiles ${ }^{9}$ like allylic halides, acyl chlorides, trialkyltin halides, enones, 1-alkynyl halides and aldehydes in good to excellent yields, giving polyfunctional thioesters of type 9 and polyfunctional phenylthioethers of type 10 (Scheme II and Table I).

\section{Scheme II}<smiles>CCSC(=O)c1ccccc1</smiles>

3<smiles>[R]C([R]Cl)c1ccccc1</smiles>

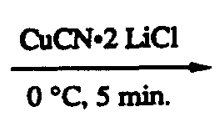

$\frac{\mathrm{CuCN} \cdot 2 \mathrm{LiCl}}{0^{\circ} \mathrm{C}, 5 \mathrm{~min} .}$<smiles>CCNC(=O)CSC(=O)c1ccccc1</smiles>

8

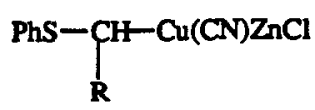

7

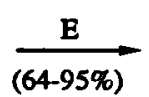

(64-95\%)

$\frac{E}{(70-92 \%)}$<smiles>[R]C(F)c1ccccc1</smiles>

10 
The zinc-copper $\alpha$-thiocarbanions 7 were found to be less reactive than copper reagents derived from primary or secondary alkylzinc halides and did not react under various reaction conditions with diethyl benzylidenemalonate or nitrostyrene. Similarly, the more stabilized reagent 8 reacted only with allylic bromides, acid chlorides and tributyltin chloride. No reaction was observed with benzaldehyde, 6-acetoxy-1-nitrocyclohexene, ${ }^{10}$ dimethyl acetylenedicarboxylate and 1,3-dichloro- 2-phenylthio-1-propene. ${ }^{11}$ It should be mentioned that similar lithioalkylthio derivatives display a far higher reactivity. Unfortunarely, they cannot bear functional groups due to the high reactivity of the carbon-lithium bond. 7 The coupling of the zinc-copper reagent $7 \mathrm{a}$ with 1-bromo-1-octyne $\left(0.75\right.$ eq. , THF $\left.-60^{\circ} \mathrm{C}, 12 \mathrm{~h}\right)$ produces the propargylic thioether $10 \mathrm{a}$ in $70 \%$ yield (entry 1 of Table I).

Table I. Thioesters of Type 9 and Phenylthio Ethers of Type 10 Obtained by the Reaction of the Zinc-Copper $\alpha$-Thiocarbanions 7a-7e and 8 with Electrophiles.

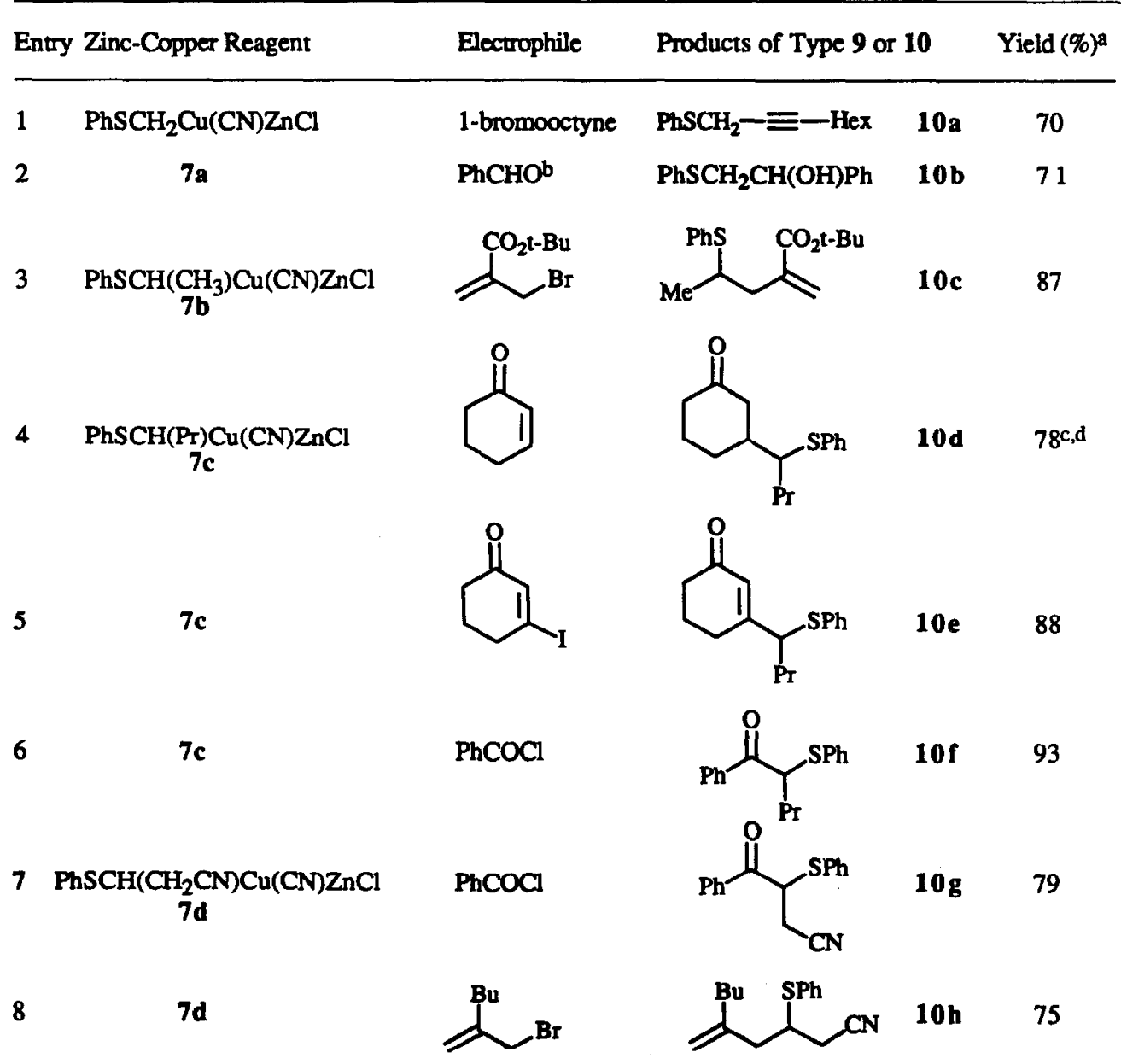




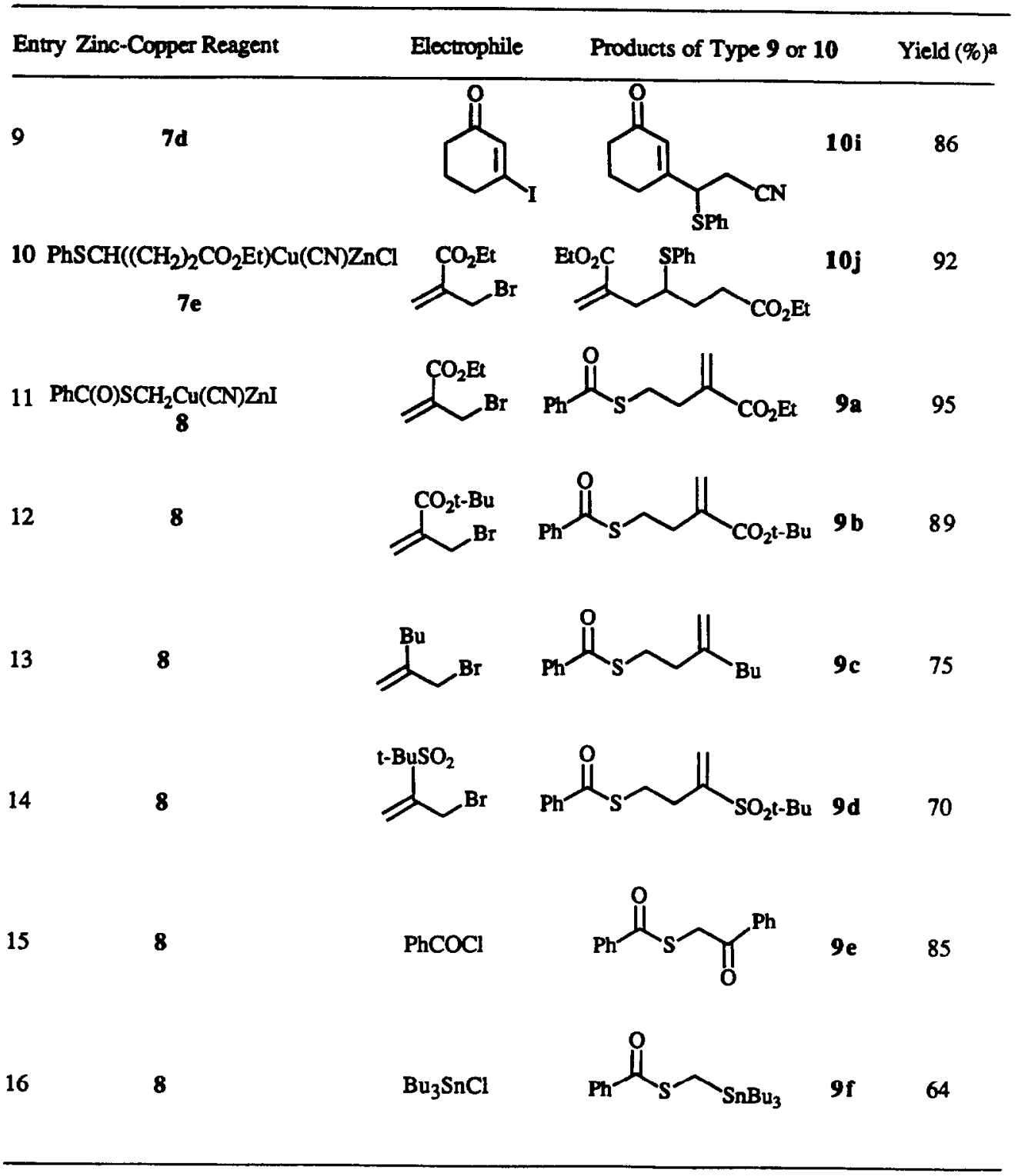

All yields refer to isolated yields of analytically pure products (see Experimental Section); b The reaction is performed in the presence of $\mathrm{BF}_{3}{ }^{\circ} \mathrm{OEt}_{2}$ (2 equiv.); ${ }^{C}$ The thioether $10 \mathrm{~d}$ is obtained as a $1: 1$ mixture of diastereoisomers; $d$ The reaction is performed in the presence of $\mathrm{Me}_{3} \mathrm{SiCl}$ (ca. 1.5 equiv.)

In the presence of $\mathrm{BF}_{3} \cdot \mathrm{OEt}_{2}$ ( 2 equiv.), the organometallic $7 \mathrm{a}$ adds to benzaldehyde ( 0.5 eq.) under mild conditions $12\left(-78^{\circ} \mathrm{C}\right.$ to $-20^{\circ} \mathrm{C}, 2 \mathrm{~h}$, entry 2$)$ leading to the $\beta$-hydroxy thioether 10b. The coupling of allylic bromides with the reagents $7 \mathrm{~b}, 7 \mathrm{~d}, 7 \mathrm{e}$ and 8 proceed in excellent 
yields (70-95\%) affording the homoallylic phenylthioethers $10 c, h, j$ (entries 3,8 and 10) and the homoallylic thioesters 9a-d (entries 11-14). Interestingly, the thioesters 9a and 96 undergo a ring closure when treated with base ( $\mathrm{NaH}\left(4.5\right.$ equiv.), EtOH, $25^{\circ} \mathrm{C}, 0.5 \mathrm{~h}$ ) affording, in both cases, exclusively the disfavored 5-Endo-Trig ${ }^{13}$ tetrahydrothiophenes $11 \mathrm{a}$ and $11 \mathrm{~b}$ in $67 \%$ and $82 \%$ yields, respectively (Scheme III). No methylene thiobutyrolactone 12 could be detected in the crude reaction mixture. The Michal addition of $7 \mathrm{c}$ to cyclohexenone $(0.63 \mathrm{cq}$.) in the presence of<smiles>C=C1CCSC1=O</smiles>

12

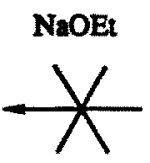

9a: $\mathbf{R}=\mathbf{E t}$

$\mathrm{Me}_{3} \mathrm{SiCl}^{14}$ (2 equiv.) produces, with a satisfactory yield, the 1,4-adduct 10d as a 1:1 mixture of diastereoisomers (THF, $-78{ }^{\circ} \mathrm{C}$ to $25^{\circ} \mathrm{C}$, overnight; 78\% yield; entry 4). 3-Iodo-2-cyclohexen-1one ${ }^{15}$ reacts readily with the zinc-copper $\alpha$-thiocarbanions $7 \mathrm{c}$ and $7 \mathrm{~d}$ giving after an addition-elimination reaction (THF, $-78^{\circ} \mathrm{C}$ to $20^{\circ} \mathrm{C}, 12 \mathrm{~h}$ at $20^{\circ} \mathrm{C}$ ), the 3-substituted enones $10 \mathrm{e}$ and $10 \mathrm{i}$ in $88 \%$ and $86 \%$ yields, respectively (entries 5 and 9). The reaction of $7 \mathrm{c}, 7 \mathrm{~d}$ or 8 with benzoyl chloride (0.5-0.62 equiv) gives the $\alpha$-thioketones $10 \mathrm{f}, 10 \mathrm{~g}$ and $9 e$ in $93 \%, 72 \%, 85 \%$ yields, respectively (entries 6,7 , and 15 ). Finally, the stannylation of 8 by tributyltin chloride furnishes the tin derivative $9\left(-20^{\circ} \mathrm{C}, 12 \mathrm{~h}\right)$ in $64 \%$ yield (entry 16$)$.

Attempts to prepare $\beta$-sulfur substituted zinc organometallics did not succeed. Thus, 2-iodoethyl isopropyl sulfoxide could not be converted to the corresponding zinc reagent; this may be due to the high propensity of such $\beta$-functionalized organometallics to undergo elimination reactions. The introduction of sulfur functionalities in the $\%$ position to the carbon-metal bond was more successful. The readily available 3-iodopropyl phenyl sulfide $4,2013,3$-iodopropyl phenyl sulfoxide 14 and 3-iodopropyl phenyl sulfone 15 were converted under mild conditions to the corresponding zinc organometallics 16a-c. Interestingly, whereas the sulfide 13 requires a reaction temperature of $40^{\circ} \mathrm{C}$ to insert zinc $\left(40^{\circ} \mathrm{C}, 3 \mathrm{~h}\right)$, the sulfoxide 14 reacts within $0.5 \mathrm{~h}$ at 25 ${ }^{\circ} \mathrm{C}$, showing that the sulfoxide in close proximity to the carbon-iodine bond functions like other polar groups $\left(\mathrm{CN}, 4 \mathrm{~d}, 16 \mathrm{P}(\mathrm{O})(\mathrm{OEt})_{2}{ }^{5 \mathrm{~d}}\right)$ is greatly facilitating the formation of the organozinc reagent. This effect may be explained by assuming that the polar group (cyanide, sulfoxide or phosphonate) complexes efficiently to the zinc surface, and that this complexation facilitates the initial electron transfer from zinc to the carbon-iodine bond, and thus enhances the rate of organozine formation. It was also found that 4-iodo-2-(tert-butylsulfonyl)-1-butene 17, which is readily available from 3-bromo-2-(tert-butylsulfonyl)-1-propene 1718 using a direct iodomethyl homologation $3 \mathrm{a}$ developed previously in our laboratories $\left(\mathrm{ICH}_{2} \mathrm{ZnI}\left(3.5\right.\right.$ equiv.), THF, $0-5{ }^{\circ} \mathrm{C}, 15$ $h ; 78 \%$ yield), can be readily converted into the corresponding zinc organometallic 19 (THF, $40-45^{\circ} \mathrm{C}, 2.5 \mathrm{~h} ;>85 \%$ yield; Scheme IV). The zinc reagents $16 \mathrm{a}-\mathrm{c}$ were transmetallated to the respective zinc- copper reagents $20,21,22$ 


\section{Scheme IV}
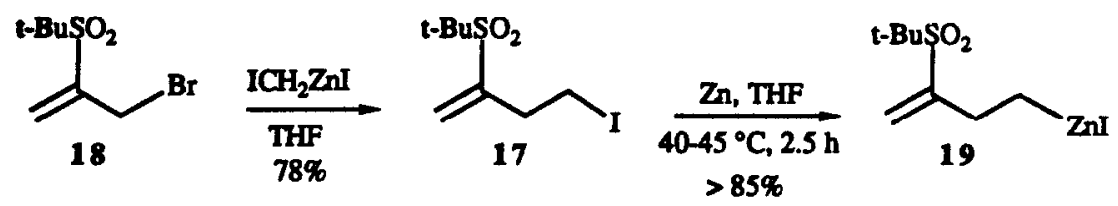

and 23 (CuCN.2 $\mathrm{LiCl}$ (1.0 equiv.), $-10^{\circ} \mathrm{C}, 5 \mathrm{~min}$.) which were found to react with allylic bromides, enones, benzoyl chloride and trimethyltin chloride in excellent yields (Table II). The allylation with all four reagents $20-23$ with tert-butyl or ethyl ( $\alpha$-bromomethyl)acrylate ${ }^{18}$ affords

$\operatorname{PhS}\left(\mathrm{O}_{n}\left(\mathrm{CH}_{2}\right)_{3} \mathrm{ZnI}\right.$

16a: $n=0$
16b: $n=1$
16c: $n=2$
$\mathrm{PhS}(\mathrm{O})_{n}\left(\mathrm{CH}_{2}\right)_{3} \mathrm{Cu}(\mathrm{CN}) \mathrm{ZnI}$

20: $n=0$

21: $n=1$

22: $n=2$

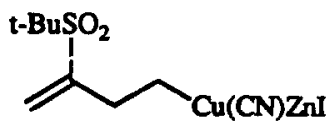

23

the desired allylated products 24a, 25a, 26, 27a in 85-90\% yield (entries $1,10,12,13$ of Table II). The Michael addition to an enone such as 2 -cyclohexen-1-one ( 0.75 equiv.) in the presence of chlorotrimethylsilane (2 equiv.) gives the 1,4-adduct $24 \mathrm{~b}$ (THF, $-78^{\circ} \mathrm{C}$ to $25^{\circ} \mathrm{C}$, ovemight; $84 \%$ yield, entry 2). An addition-elimination of 20 or 23 to 3-iodo-2-cyclohexen-1-one ( 0.75 equiv.; $-78{ }^{\circ} \mathrm{C}$ to $25^{\circ} \mathrm{C}, 15 \mathrm{~h}$ ) affords the 3 -substituted cyclohexenones $24 \mathrm{c}$ and $27 \mathrm{~b}$ in $85 \%$ and $93 \%$ yields respectively (entries 13 and 14 of Table II).

Table II. Products of Type 24-27 Obtained by the Reaction of the $\psi$-Zinc-Copper Reagents 20-23 with Electrophiles.

$\begin{array}{llll}\text { Entry Copper Reagent } & \text { Electrophile } & \text { Products of Type } 23 & \text { Yield (\%) }\end{array}$

$1 \quad \mathrm{PhS}\left(\mathrm{CH}_{2}\right)_{3} \mathrm{Cu}(\mathrm{CN}) \mathrm{ZnI}$<smiles>C=C(CBr)C(=O)OBr</smiles><smiles>C=C(CC(C)(C)CCC[SnH+])C(=O)OCCC</smiles><smiles>O=C1C=CCCC1</smiles><smiles>CC(C)(CCC[SnH]c1ccccc1)C1CCCC(=O)C1</smiles><smiles>O=C1C=C(I)CCC1</smiles><smiles>CC(C)(CCC[SnH]c1ccccc1)C1=CC(=O)CCC1</smiles>

$\mathrm{PhCOCl}$<smiles>CC(CCCS)(C(=O)c1ccccc1)c1ccccc1</smiles> 


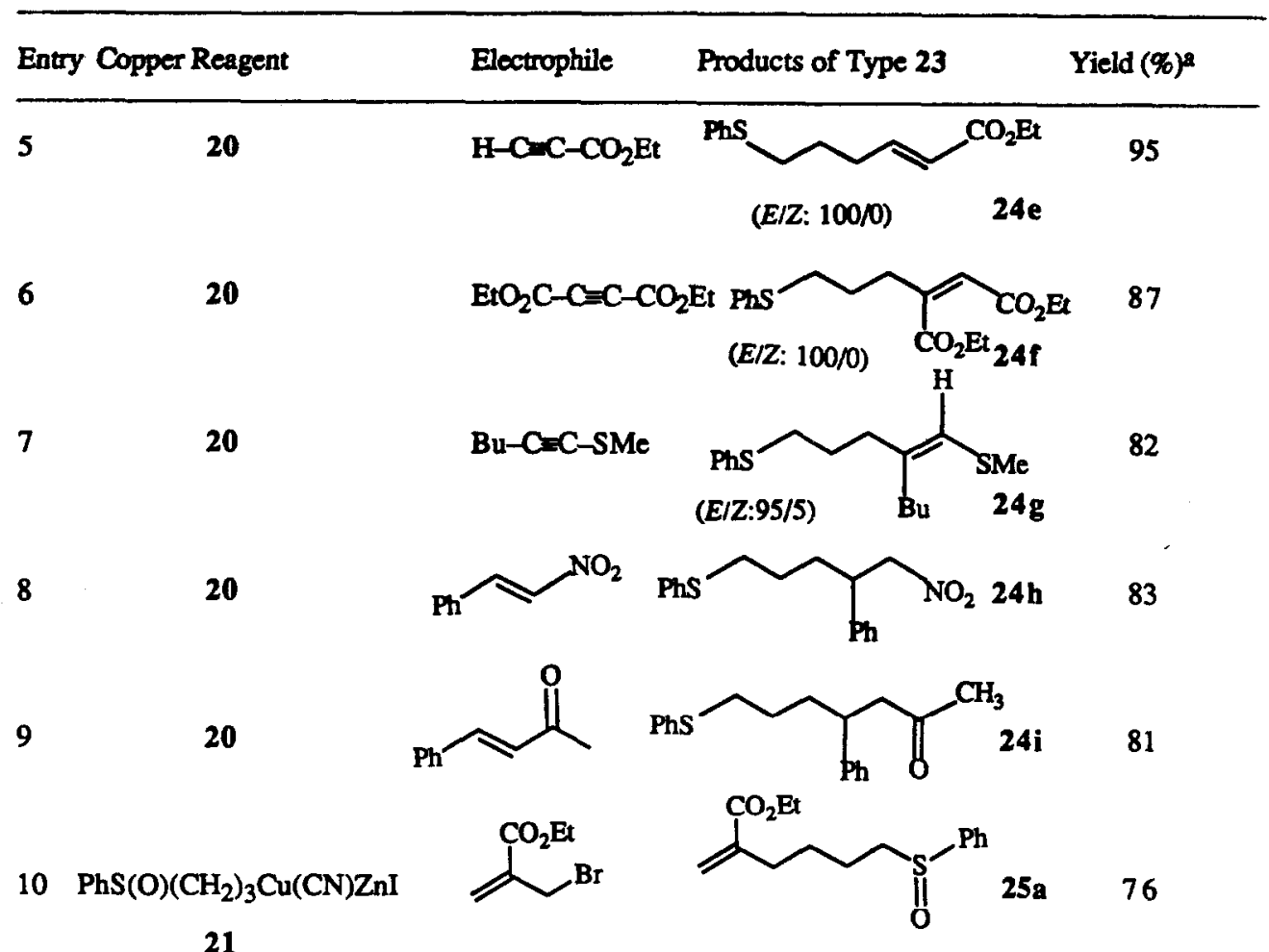
21

11

21<smiles>CS(C)(C)SCCCS(=O)c1ccccc1</smiles>

$12 \mathrm{PhSO}_{2}\left(\mathrm{CH}_{2}\right)_{3} \mathrm{Cu}(\mathrm{CN}) \mathrm{ZnI}$<smiles>CCOC(=O)C([14CH3])=C[14CH2]Br</smiles><smiles>C=C(CCC)C(=O)OCC</smiles>
$\mathrm{SO}_{2} \mathrm{Ph} \quad 26$ 88

13<smiles>C=C(CCC([AlH2])C#N)C(C)(C)O</smiles>

14 23<smiles>C=C(CBr)C(=O)OCCBr</smiles><smiles>C=C(CCCC(=C)[R15]([O-])([O-])[SH3])C(=O)O</smiles>
27a 90<smiles>O=C1C=C(I)CCC1</smiles><smiles>C=C(CCC1=CC(=O)CCC1)C(=O)O[Na]</smiles> 
The acylation of 20 with benzoyl chloride $\left(0.75\right.$ equiv., $-10^{\circ} \mathrm{C}, 10 \mathrm{~h} ; 80 \%$ yield, entry 4$)$ furnishes the desired ketone $24 \mathrm{~d}$. The carbometallation of activated alkynes such as ethyl propiolate, diethyl acetylenedicarboxylate, 1-methylthio-1-hexyne with 20 proceeds in excellent yields (82\%-95\%) and affording the $5 y$ adducts $24 \mathrm{e}-24 \mathrm{~g}$ with high stereoselectivity (entries 5-7 of Table II). The Michael additions of 20 to nitrostyrene and benzylideneacetone gives the expected adducts $24 \mathrm{~h}$ and $24 \mathrm{i}$ in $83 \%$ and $81 \%$ yields respectively (entries 8 and 9 of Table II). The reaction of trimethyltin chloride with reagent 21 proceeds readily (THF, $-20^{\circ} \mathrm{C}$ to $25^{\circ} \mathrm{C}, 0.5$ h; $90 \%$ yield; entry 11) leading to the trimethyltin substituted sulfoxide 25b.

\section{CONCLUSION}

The preparation of zinc $\alpha$-thiocarbanions has several synthetic advantages over the more conventional $\alpha$-thiocarbanions. Besides their considerably higher thermal stability (no decomposition at $25^{\circ} \mathrm{C}$ for $10 \mathrm{~h}$ ), these reagents show a very high functional group tolerance, allowing the synthesis of highly functionalized $\alpha$-thiocarbanions. As a consequence of this excellent compatibility with functional groups, the carbon-zinc bond was found to be very unreactive. However, the transmetallation with $\mathrm{CuCN} \cdot 2 \mathrm{LiCl}$ affords zinc-copper reagents which display an excellent reactivity toward many types of electrophiles as shown in Table I. Although $\beta$-thiosubstituted zinc organometallics could not be prepared, several $\gamma$-thiosubstituted zinc compounds bearing sulfoxide, sulfone and sulfide functionalities could be obtained. All of these organometallics readily form new carbon-carbon bonds after a transmetallation to the corresponding copper compound. This study also showed that an $\alpha$-thio functionality considerably facilitates the initial insertion of zinc into the carbon-halide bond. In fact, $\alpha$-chloroalkyl phenyl sulfides were found to be the first class of organic halides for which a direct insertion of zinc into a carbon-chlorine bond is possible under mild conditions.

\section{EXPERIMENTAL SECTION}

General. Unless otherwise indicated, all reactions were camied out under argon. Solvents such as THF and diethyl ether were dried and freshly distilled from sodium/benzophenone. The zinc dust was obtained from Aldrich Chemical Company, Inc. ( -325 mesh). Reactions were monitored by gas chromatography (GC) or thin layer chromatography (TLC) analysis of hydrolyzed reaction aliquots. Fourier transform infrared spectra (FT-IR) were recorded under a nitrogen atmosphere on sodium chloride plates on a Nicolet 5DXB FT-IR spectrometer. Infrared frequencies are reported in wave number units $\left(\mathrm{cm}^{-1}\right)$. Proton nuclear magnetic resonance spectra ( ${ }^{1} \mathrm{H}$ NMR) were recorded on a Brucker WM-300 (300 MHz) nuclear magnetic resonance spectrometer. Chemical shifts are reported as $d$ in units of parts per million ( $\mathrm{ppm}$ ) relative to an internal reference of tetramethylsilane $(\delta 0.00)$. Coupling constants are reported in Hertz $(\mathrm{Hz})$. Carbon-13 nuclear magnetic resonance spectra ( ${ }^{13} \mathrm{C} N \mathrm{NR}$ ) were recorded on a Bruker WM-300 (75.5 MHz) nuclear magnetic resonance spectrometer. Chemical shifts are reported as $\delta$ in units of parts per million (ppm) relative to chloroform-d $(\delta 77.0)$ as an internal reference. Mass spectra (MS) and exact mass spectra were recorded on a VG-70-250 S mass spectrometer. The ionization methods used were desorption chemical ionization (CI) and electron impact ionization (EI). Spectra are reported in units of mass to charge and relative intensity.

Breparation of $\alpha$-chloroalkyl phenyl sulfides and related starting materials. All reported $\alpha$-chloroalkyl phenyl sulfides were prepared according to literature procedures. ${ }^{6}$

Typical procedure. $N$-Chlorosuccinimide $(2.67 \mathrm{~g}, 22 \mathrm{mmol})$ freshly recrystallized from benzene was added between $5-10^{\circ} \mathrm{C}$ in three portions within $15 \mathrm{~min}$ to a solution of an alkyl phenyl sulfide $(20 \mathrm{mmol})$ in $20 \mathrm{~mL}$ of $\mathrm{CCl}_{4}$. The reaction mixture was stirred two hours at $25^{\circ} \mathrm{C}$ and poured into water $(100 \mathrm{~mL})$. The two layers were separated and the aqueous phase was extracted with $\mathrm{CCl}_{4}$ 
$(2 \times 50 \mathrm{~mL})$. The combined organic phase was washed with brine $(50 \mathrm{~mL})$, dried over anhydrous $\mathrm{MgSO}_{4}$ and filtered. After evaporation of the solvents, the crude product was used directly for the formation of the zinc organometallics. Attempts to further purify the crude chloroalkyl phenyl sulfide by distillation led to the decomposition of the product. The purity was determined by ${ }^{1} \mathrm{H}$ NMR spectroscopy and was usually $>90 \%$.

(1-Chloro-2-cyanolethyl phenyl sulfide19. ${ }^{1} \mathrm{H} \mathrm{NMR}\left(\mathrm{CDCl}_{3}, 300 \mathrm{MHz}\right): 8$ 7.65-7.57 (m, 2H), 7.46-7.38 (m, 3H), $5.35(\mathrm{t}, 1 \mathrm{H}, J=6.0 \mathrm{~Hz}), 3.05(\mathrm{~d}, 2 \mathrm{H}, J=6.0 \mathrm{HZ})$.

3-Chloropropyl phenyl sulfide 20 (bp $120-130^{\circ} \mathrm{C}(0.02$ Torr)) as well as 3-(phenyithio)propionitrile 21 were prepared according to the literature, whereas ethyl 4-(phenylthio) butanoate was prepared by the reaction of PhSLi with ethyl 4-iodobutyrate in THF $\left(25^{\circ} \mathrm{C}, 8 \mathrm{~h}, 85 \%\right.$ yield; bp 124-127 ${ }^{\circ} \mathrm{C}(0.6 \mathrm{mmHg}$; compare with ref. 22 )

Preparation of the alkyl iodides $13-15$ and 17.

3-Iodopropyl phenyl sulfide 13 was prepared according to the literature 20 by refluxing a mixture of 3-chloropropyl phenyl sulfide $(18.6 \mathrm{~g}, 100 \mathrm{mmol})$ and sodium iodide $(30 \mathrm{~g}, 200 \mathrm{mmol})$ in 50 $\mathrm{mL}$ of acetone for $12 \mathrm{~h}$. After the usual work-up, the residue was distilled under reduced pressure $\left(113-115^{\circ} \mathrm{C} ; 0.2 \mathrm{mmHg}\right.$ ) to obtain 3-iodopropyl phenyl sulfide in $85 \%$ yield $(23.6 \mathrm{~g})$. IR (neat): $3072(\mathrm{~s}), 3056(\mathrm{~s}), 2956$ (br s), $1584(\mathrm{~s}), 1480(\mathrm{~s}), 1438(\mathrm{~s}), 1210(\mathrm{~s}), 738(\mathrm{~s}), 690(\mathrm{~s}) \mathrm{cm}^{-1} ;{ }^{1} \mathrm{H}$ NMR $\left(\mathrm{CDCl}_{3}, 300 \mathrm{MHz}\right): \delta 7.4-7.15(\mathrm{~m}, 5 \mathrm{H}), 3.28(\mathrm{t}, 2 \mathrm{H}, J=6.0 \mathrm{~Hz}), 2.98(\mathrm{t}, 2 \mathrm{H}, J=6.0$ $\mathrm{Hz}), 2.1-2.0(\mathrm{~m}, 2 \mathrm{H}) ;{ }^{13} \mathrm{C} \mathrm{NMR}\left(\mathrm{CDCl}_{3}, 75.5 \mathrm{MHz}\right): \delta 135.5,129.5,128.8,126.1,34.2$, $32.3,4.7$.

3-Iodopropyl phenyl sulfoxide 14. A solution of m-chloroperbenzoic acid $(6.0 \mathrm{~g}, 19 \mathrm{mmol}, 50 \%)$ in $50 \mathrm{~mL}$ of dichloromethane was added to a solution of 3-iodopropyl phenyl sulfide $\left(5.3 \mathrm{~g}_{3} 19\right.$ $\mathrm{mmol}$ ) in $20 \mathrm{~mL}$ of dichloromethane at $0^{\circ} \mathrm{C}$ for $10 \mathrm{~min}$. A white precipitate was formed after addition is over and stirred for another $30 \mathrm{~min}$. at $5-10^{\circ} \mathrm{C}$. After the usual work-up, the crude product was purified by flash chromatography (hexane:ethyl acetate, 7:3) giving the pure sulfoxide 14 (4.58 g, 82\% yield). IR (neat): 3053 (s), 2958 (br s), 1477 (s), $1443(\mathrm{~s}), 1288(\mathrm{~m}), 1207$ (m), 1041 (m), $749(\mathrm{~s}), 691$ (s) $\mathrm{cm}^{-1}$; ${ }^{1} \mathrm{H}$ NMR $\left(\mathrm{CDCl}_{3}, 300 \mathrm{MHz}\right): \delta$ 7.7-7.5 (m, 5H) 3.34-3.2 $(\mathrm{m}, 2 \mathrm{H}), 3.04-2.94(\mathrm{~m}, 1 \mathrm{H}), 2.9-2.8(\mathrm{~m}, 1 \mathrm{H}), 2.4-2.25(\mathrm{~m}, 1 \mathrm{H}), 2.22-2.05(\mathrm{~m}, 1 \mathrm{H})$; $3 \mathrm{C}$ NMR $\left(\mathrm{CDCl}_{3}, 75.5 \mathrm{MHz}\right): \delta 142.9,130.7,128.9,123.5,56.7,25.4,3.8 ; \mathrm{MS}$ (EI): 41(95), 49(51), $78(32), 84(41), 97(11), 125(34), 169(100), 294(5)$. Exact mass calcd. for $\mathrm{C}_{9} \mathrm{H}_{11}$ IOS: 293.9575. Observed 293.9567.

3-lodopropyl phenyl sutfone 15: 3-chloropropyl phenyl sulfone $(2.18 \mathrm{~g}, 10 \mathrm{mmol})$ and sodium iodide ( $3.0 \mathrm{~g}, 20 \mathrm{mmol}$ ) in $20 \mathrm{~mL}$ of acetone was refluxed for $12 \mathrm{~h}$ to obtain 3-iodopropyl phenyl sulfone $(2.82 \mathrm{~g}, 91 \%$ yield). After the usual work-up, the crude material was used for carrying out the reactions.

IR (neat): 3063 (br s), 2962 (br s), 1584 (s), 1403 (m), 1283 (m), 1094 (m), 1024 (s), 998 (s), $977(\mathrm{~s}), 946(\mathrm{~s}), 779(\mathrm{~m}), 691 \mathrm{(s)} \mathrm{cm}^{-1}$; H NMR $\left._{\text {N }} \mathrm{CDCl}_{3}, 300 \mathrm{MHz}\right): 87.96-7.9(\mathrm{~m}, 2 \mathrm{H})$, 7.7-7.56 (m, 3H), 3.3-3.2 (m, 4H), 2.32-2.2 (m, 2H); $\left.{ }^{3} \mathrm{C} \mathrm{NMR} \mathrm{(CDCl}, 75.5 \mathrm{MHz}\right): 8138.7$, $133.6,129.1,127.6,56.4,26.3,2.7$; MS (EI): 41 (48), 51 (18), 77 (54), 125 (17), 141 (28), $183(100), 311[\mathrm{M}+\mathrm{H}]^{+}(7)$. Exact mass calcd. for $\mathrm{C}_{9} \mathrm{H}_{11} \mathrm{IO}_{2} \mathrm{SH}$ : 310.9602 . Observed: 310.9598 .

4-Iodo-2-(tert-butylsulfonyl)-1-butene 17: A THF solution of iodomethylzinc iodide ( $36 \mathrm{mmol}$ in $20 \mathrm{~mL}$ of THF) prepared from diiodomethane $(10.7 \mathrm{~g}, 40 \mathrm{mmol})$ and zinc foil $(2.6 \mathrm{~g}, 40 \mathrm{mmol})$ in $20 \mathrm{~mL}$ of THF at $25-26^{\circ} \mathrm{C}(3 \mathrm{~h})$ was added at $-10^{\circ} \mathrm{C}$ to a THF solution of 3-bromo-2-(tertbutylsulfonyl)-1-propene $18(1.96 \mathrm{~g}, 8 \mathrm{mmol})$, Cul $(1.52 \mathrm{~g}, 8 \mathrm{mmol})$, Lil $(2.14 \mathrm{~g}, 16 \mathrm{mmol})$ in $10 \mathrm{~mL}$ of THF which had been stirred at $0^{\circ} \mathrm{C}$ for $0.5 \mathrm{~h}$. After stirring the reaction mixture at $0^{\circ} \mathrm{C}$ overnight, the reaction mixture was worked up as described above. Flash chromatography of the residue (hexane:dichloromethane 3:2) gives $1.73 \mathrm{~g}(5.7 \mathrm{mmol} ; 11 \%$ yield) of the pure sulfone 17 . IR (neat): 3022 (s), 2987 (s), 2975 (s), 2935 (s), $1478(\mathrm{~m}), 1294(\mathrm{~m}), 1252(\mathrm{~s}), 1216(\mathrm{~m}), 1197$ (s), $1109(\mathrm{~s}), 1102(\mathrm{~s}), 960(\mathrm{~s}) \mathrm{cm}^{-1}$; ${ }_{\mathrm{H} \mathrm{NMR}}\left(\mathrm{CDCl}_{3}, 300 \mathrm{MHz}\right): \delta 6.28(\mathrm{~s}, 1 \mathrm{H}), 6.08(\mathrm{~s}, 1 \mathrm{H})$, $3.35(\mathrm{t}, 2 \mathrm{H}, J=7.5 \mathrm{~Hz}), 2.95(\mathrm{t}, 2 \mathrm{H}, J=7.5 \mathrm{~Hz}), 1.35(\mathrm{~s}, 9 \mathrm{H}) ;{ }^{13} \mathrm{C}, \mathrm{NMR}(\mathrm{CDCl}, 75.5 \mathrm{MHz}):$ $\delta 145.9,130.3,60.5,36.4,23.6,1.2 ; \mathrm{MS}$ (Cl with methane): 89 (7), $105(17)$, $119(54), 136$ (12), $233(12), 247(100), 264(15), 275(17), 287(8), 303[\mathrm{M}+\mathrm{H}]^{+}(7), 320\left[\mathrm{M}+\mathrm{NH}_{4}\right]^{+}(40)$. Exact mass calcd. for $\mathrm{C}_{8} \mathrm{H}_{15} \mathrm{O}_{2} \mathrm{ISH}$ : 302.9915 . Observed: $302.9907[\mathrm{M}+\mathrm{H}]^{+}$. 
Iodomethylthiobenzoate 5: A solution of chloromethyl thiobenzoate $(12 \mathrm{~g}, 60 \mathrm{mmol})$ in $60 \mathrm{~mL}$ of actone was sitrred for $5 \mathrm{~h}$ at $25^{\circ} \mathrm{C}$ with $\mathrm{NaI}(30 \mathrm{~g}, 200 \mathrm{~mol})$. After addition of hexane $(300 \mathrm{~mL})$, filtration of the sodium salts, evaporation of solvents, a crude oil was obtained $(14.2 \mathrm{~g}, 89 \%$ yield, purity ca. 85\%) which was used directly for the formation of the zinc reagent 3. IR (neat): 3059 (m), $3031(\mathrm{~m}), 1673(\mathrm{~s}), 1595(\mathrm{~s}), 1581(\mathrm{~s}), 1448(\mathrm{~s}), 1356(\mathrm{~m}), 1314(\mathrm{~m}), 1306(\mathrm{~m}), 1207(\mathrm{~s})$, $1176(\mathrm{~s}), 1145$ (s), 1000 (m), 906 (s), $772(\mathrm{~s}), 730(\mathrm{~s}), 685(\mathrm{~s}), 645(\mathrm{~s}) \mathrm{cm}^{-1} ;{ }^{1} \mathrm{H}$ NMR (CDCl $300 \mathrm{MHz}): \quad 87.95-7.86(\mathrm{~m}, 2 \mathrm{H}), 7.62-7.54(\mathrm{~m}, 1 \mathrm{H}), 7.47-7.38(\mathrm{~m}, 2 \mathrm{H}), 4.58(\mathrm{~s}, 2 \mathrm{H}) ; 13 \mathrm{C}$ NMR $\left(\mathrm{CDCl}_{3}, 75.5 \mathrm{MHz}\right): \delta 188.78,136.04,134.08,128.81,127.54,-8.85$; $\mathrm{MS}$ (EI): 51 (12.4), 77 (29.1), 105 (100.0), 151 (11.7). Exact mass calcd. for $\mathrm{C}_{8} \mathrm{H}_{7} \mathrm{IOSH}$ : 278.9341 . Observed: 278.9346 .

General procedure for the preparation of $\alpha$-phenylthioalkylzinc chlorides of type 1 . A dry, 100 $\mathrm{mL}$, three-necked flask equipped with a magnetic stirring bar, a $25 \mathrm{~mL}$ pressure equalizing addition funnel bearing a rubber septum, a three-way stopcock and a thermometer, was charged with zinc dust $(1.95 \mathrm{~g}, 30 \mathrm{mmol}$, Aldrich, $-325 \mathrm{mesh})$ and was flushed three times with argon. 1,2-Dibromoethane (200 mg, ca. $1 \mathrm{mmol}$ ) in $2 \mathrm{~mL}$ of THF was added and the zinc suspension was gently heated with a heat gun until ebullition of the solvent. After stirring the reaction mixture for a minute, the same activation process was repeated twice and chlorotrimethylsilane $(0.15 \mathrm{~mL}, 1.2$ mmol) was added. After 10 min of sitring, the $\alpha$-chloroalkyl phenyl sulfide $(10 \mathrm{mmol})$ dissolved in $7 \mathrm{~mL}$ of THF was added dropwise over $10 \mathrm{~min}$. The internal reaction temperature raises from $25^{\circ} \mathrm{C}$ to $45^{\circ} \mathrm{C}$. The reaction mixture was then stirred for $1.5-2 \mathrm{~h}$ at $25^{\circ} \mathrm{C}$ in the case of the alkyl substituted chlorides 1, for $3 \mathrm{~h}$ in the case of 3-chloro-3-phenylthiopropionitrile and for $10 \mathrm{~h}$ in the case of ethyl 4-chloro-4-(phenylthio)butanoate. The completion of the reaction was monitored by GLC analysis of hydrolyzed reaction aliquots and yield of ca. $85 \%$ of the desired organozinc compound 1 were usually obtained. The excess zinc was allowed to settle and the resulting clear solution is ready to use for further transformations.

Breparation of benzovlthioxymethylainciodide 3 . The same activation procedure was used and the iodomethylthiobenzoate 5 was added to zinc dust as a $1.5 \mathrm{M}$ THF solution at $8{ }^{\circ} \mathrm{C}$. The insertion was completed after $1 \mathrm{~h}$ at this temperature affording the desired organozinc reagent 3 in $>90 \%$ yield.

Breparation of $\gamma$-thiosubstituted organozinc iodides: 3-Iodopropyl phenyl sulfide, sulfoxide and sulfone 13,14 and 15 were converted to the corresponding zinc reagents 16a-c under the above described conditions. After the addition of the thiosubstituted iodides as a 2.0-2.5 M THF solution, the reaction mixture was stirred for $4 \mathrm{~h}$ at $40^{\circ} \mathrm{C}$ with the sulfide, $0.5 \mathrm{~h}$ at $25^{\circ} \mathrm{C}$ with the sulfoxide and $1 \mathrm{~h}$ at r.t. with the sulfone. The yields of organozinc iodides were $\mathrm{ca}$. $90 \%$. In the case of 3-tert-butylsulfonyl-3-butenyl iodide 17, the corresponding zinc reagent 19 was formed in over $85 \%$ yield after a reaction time of $2.5 \mathrm{~h}$ at $40-45^{\circ} \mathrm{C}$.

Conversion of thio-substituted organozinc halides to the corresponding copper reagents 7 g-e. 8. 20-23. A dry, $100 \mathrm{~mL}$, three-necked flask equipped with a magnetic stirring bar, a $25 \mathrm{~mL}$ pressure equalizing addition funnel bearing a rubber septum, a three-way stopcock and a thermometer was charged with a mixture of $\mathrm{LiCl}\left(0.84 \mathrm{~g}, 20 \mathrm{mmol}\right.$; dried under vacuum at $130^{\circ} \mathrm{C}$ for $2 \mathrm{~h})$ and $\mathrm{CuCN}(0.89 \mathrm{~g}, 10 \mathrm{mmol})$ and was flushed three times with argon. The mixture was dissolved in $10 \mathrm{~mL}$ of dry THF. The resulting yellow-greenish solution was cooled to $-60^{\circ} \mathrm{C}$ and a THF solution of the thiosubstituted organozinc compound was added via a syringe. The reaction mixture was warmed to $0^{\circ} \mathrm{C}$ and cooled back to $-70^{\circ} \mathrm{C}$ after 5 min. Various electrophiles (usually $7 \mathrm{mmol}$ ) were then added and allowed to react for various times and temperatures (see specific description of the products 9,10 and 23). After the completion of the reaction determined by GLC analysis, the reaction mixture was poured into a saturated aqueous ammonium chloride solution $(50 \mathrm{~mL})$ and ammonium hydroxyde $(50 \mathrm{~mL})$ and was diluted with ether $(100 \mathrm{~mL})$. After separation of the two layers, the aqueous phase was extracted with ether ( $2 \times 100 \mathrm{~mL}$ ) and the combined organic layer was washed with water $(100 \mathrm{~mL})$, brine solution $(100 \mathrm{~mL})$ and dried over $\mathrm{MgSO}_{4}$. After filtration and evaporation of the solvent, the resulting crude product was purified by flash chromatography affording the desired products with the yields indicated in Table I and II. GLC analysis of all of these products indicateds a purity greater than $98 \%$. 
Analytical data for products 9a f Table D.

Ethyl 2-(2-benzoylthioxyethyl)acrylate 9a. Prepared by the reaction of ethyl $\alpha$-(bromomethyl)acrylate (0.5 equiv.) with 8: $-78^{\circ} \mathrm{C}$ to $0{ }^{\circ} \mathrm{C}, 30 \mathrm{~min}$.; $95 \%$ yield; purified by flash chromatography (hexane:ether, 10:1). IR (neat): 3061 (br s), 2981 (m), 2936 (m), 2906 (br s), $1715(\mathrm{~s}), 1664(\mathrm{~s}), 1631$ (m), $1606(\mathrm{~m}), 1581(\mathrm{~m}), 1448(\mathrm{~m}), 1407(\mathrm{~m}), 1369(\mathrm{~m}), 1335(\mathrm{~m})$, $1314(\mathrm{~m}), 1304(\mathrm{~m}), 1276(\mathrm{~m}), 1206(\mathrm{~s}), 1186(\mathrm{~s}), 1170(\mathrm{~s}), 1126(\mathrm{~m}), 1027(\mathrm{~m}), 948(\mathrm{~m}), 911$ (s), $773(\mathrm{~m}), 688(\mathrm{~s}), 647(\mathrm{~s}) \mathrm{cm}^{-1}$; ${ }_{\mathrm{H}} \mathrm{NMR}\left(\mathrm{CDCl}_{3}, 300 \mathrm{MHz}\right): 87.96-7.92(\mathrm{~m}, 2 \mathrm{H})$, $7.57-7.52(\mathrm{~m}, 1 \mathrm{H}), 7.45-7.39(\mathrm{~m}, 2 \mathrm{H}), 6.23(\mathrm{~d}, 1 \mathrm{H}, J=1.2 \mathrm{~Hz}), 5.64(\mathrm{q}, 1 \mathrm{H}, J=1.2 \mathrm{~Hz}), 4.22$ $(\mathrm{q}, 2 \mathrm{H}, J=7.2 \mathrm{~Hz}), 3.23(\mathrm{t}, 2 \mathrm{H}, J=7.5 \mathrm{~Hz}), 2.66(\mathrm{td}, 2 \mathrm{H}, J=7.5 \mathrm{~Hz}, J=0.8 \mathrm{~Hz}), 1.30(\mathrm{t}$, $3 \mathrm{H}, J=7.2 \mathrm{~Hz}) ; \mathrm{MS}(\mathrm{EI}): 51(14), 77(55), 105(100), 106(10), 165(17), 264\left(0.04, \mathrm{M}^{+}\right)$. Exact mass calcd. for $\mathrm{C}_{14} \mathrm{H}_{16} \mathrm{O}_{3} \mathrm{SH}$ : 265.0898 . Observed: 265.0902 .

tert-Butyl 2-(benzoylthioxyethyl)-2-propenoate $9 \mathrm{~b}$. Prepared by the reaction of tert-butyl $\alpha$-(bromomethyl)acrylate $\left(0.65\right.$ equiv.) with 8: $-70^{\circ} \mathrm{C}$ to $0^{\circ} \mathrm{C}, 30 \mathrm{~min} ., 89 \%$ yield; purified by flash chromatography (hexane:ether, 10:1). IR (neat): 3003 (m), 2977 (m), 2932 (m), 1710 (s), 1666 (s), 1632 (m), 1596 (m), 1582 (m), $1477(\mathrm{~m}), 1448(\mathrm{~s}), 1404(\mathrm{~m}), 1392(\mathrm{~m}), 1368(\mathrm{~s})$, $1343(\mathrm{~m}), 1312(\mathrm{~m}), 1280(\mathrm{~m}), 1256(\mathrm{~m}), 1233(\mathrm{~m}), 1207(\mathrm{~s}), 1175(\mathrm{~s}), 1157(\mathrm{~s}), 1128(\mathrm{~s}), 947$ $(\mathrm{m}), 912(\mathrm{~s}), 851(\mathrm{~m}), 818(\mathrm{~m}), 773(\mathrm{~m}), 689(\mathrm{~s}), 647(\mathrm{~m}) \mathrm{cm}^{-1} ;{ }_{1} \mathrm{H}_{\mathrm{NMR}}\left(\mathrm{CDCl}_{3}, 300 \mathrm{MHz}\right): \delta$ $7.97-7.92(\mathrm{~m}, 2 \mathrm{H}), 7.58-7.52(\mathrm{~m}, 1 \mathrm{H}), 7.47-7.40(\mathrm{~m}, 2 \mathrm{H}), 6.16(\mathrm{dd}, 1 \mathrm{H}, J=14.5 \mathrm{~Hz}, J=1.56$ $\mathrm{Hz}), 5.56(\mathrm{~m}, 1 \mathrm{H}), 3.21(\mathrm{t}, 2 \mathrm{H}, J=8.0 \mathrm{~Hz}), 2.62(\mathrm{td}, 2 \mathrm{H}, J=7.5 \mathrm{~Hz}, J=0.9 \mathrm{~Hz}), 1.47(\mathrm{~s}$, 9H); $\left.{ }^{13} \mathrm{C} \mathrm{NMR} \mathrm{(CDCl}, 75.5 \mathrm{MHz}\right): \delta 191.27,165.60,139.82,137.00,133.10,128.40$, $127.03,125.51,80.64,32.18,27.95,27.78$; MS (EI): $35(21), 39(16), 41(42), 45(10), 47$ $(31), 49(69), 51(30), 57(54), 77(29), 84(60), 86(40), 105(100), 114(21)$. Exact mass calcd. for $\mathrm{C}_{16} \mathrm{H}_{20} \mathrm{O}_{3} \mathrm{SH}^{+}$: 293.1211. Observed: 293.1210.

3-Butyl-3-butenyl thiobenzoate 9c. Prepared by the reaction of 2-(bromomethyl)hexene ( 0.5 equiv.) with 8: $-70^{\circ} \mathrm{C}$ to $0^{\circ} \mathrm{C}, 30 \mathrm{~min}$.; $75 \%$ yield; purified by flash chromatography (hexane:ether, 15:1). IR (neat): 3081 (br s), 3008 (br s), 2956 (s), 2929 (s), 2871 (m), 2859 (m), 1664 (s), 1587 (br s), 1582 (br s), 1465 (br s), 1448 (m), 1207 (s), 1175 (m), 912 (s), 772 $(\mathrm{m}), 689(\mathrm{~s}), 647(\mathrm{~m}) \mathrm{cm}^{-1}$; ${ }^{1} \mathrm{H}$ NMR $\left(\mathrm{CDCl}_{3}, 300 \mathrm{MHz}\right): 87.97-7.93(\mathrm{~m}, 2 \mathrm{H}), 7.55-7.50(\mathrm{~m}$, iH), 7.43-7.38 (m, 2H), $4.81(\mathrm{~s}, 2 \mathrm{H}), 3.17(\mathrm{t}, 2 \mathrm{H}, J=7.5 \mathrm{~Hz}), 2.36(\mathrm{t}, 2 \mathrm{H}, J=7.5 \mathrm{~Hz}), 2.06$ $(\mathrm{t}, 2 \mathrm{H}, J=7.5 \mathrm{~Hz}), 1.48-1.25(\mathrm{~m}, 4 \mathrm{H}), 0.90(\mathrm{t}, 3 \mathrm{H}, J=7.2 \mathrm{~Hz}) ; 13 \mathrm{C} \mathrm{NMR}\left(\mathrm{CDCl}_{3}, 75.5\right.$ $\mathrm{MHz}): \delta 191.88,147.84,137.38,133.22,128.58,127.24,110.50,35.83,35.69,29.96$, 27.54, 22.41, 13.91; MS (EN): 41 (11), $51(10), 77(35), 105(100), 110(20), 248\left(0.49, \mathrm{M}^{+}\right)$. Exact mass calcd. for $\mathrm{C}_{15} \mathrm{H}_{20}$ OS: 248.1234 . Observed: 248.1234 .

3-tert-Butyl-3-butenyl thiobenzoate 9d. Prepared by the reaction of 3-bromo-2-tert-butylsulfonyl1-propene ( 0.5 equiv.) with $8:-70^{\circ} \mathrm{C}$ to $0^{\circ} \mathrm{C}, 1 \mathrm{~h} ; 70 \%$ yield; purified by flash chromatography (hexane:ether, 10:1). IR $\left(\mathrm{CCl}_{4}\right): 3088(\mathrm{~m}), 3071(\mathrm{~m}), 2955(\mathrm{~m}), 2930(\mathrm{~m}), 2855(\mathrm{br} \mathrm{s}), 1666$ (s), 1582 (m), 1478 (m), 1457 (br s), 1449 (m), 1301 (s), 1207 (s), 1177 (m), 1129 (m), 1107 (s), 959 (br s), $912(\mathrm{~s}) \mathrm{cm}^{-1}$; ${ }_{1} \mathrm{H} \mathrm{NMR}\left(\mathrm{CDCl}_{3}, 300 \mathrm{MHz}\right): 87.90-7.87(\mathrm{~m}, 2 \mathrm{H}), 7.52(\mathrm{t}, 1 \mathrm{H}, J$ $=7.5 \mathrm{~Hz}$ ), $7.39(\mathrm{t}, 2 \mathrm{H}, J=7.5 \mathrm{~Hz}), 6.23(\mathrm{~s}, 1 \mathrm{H}), 6.09(\mathrm{~s}, 1 \mathrm{H}), 3.25(\mathrm{t}, 2 \mathrm{H}, J=7.5 \mathrm{~Hz}), 2.76$ $(\mathrm{t}, 2 \mathrm{H}, J=7.5 \mathrm{~Hz}), 1.32(\mathrm{~s}, 9 \mathrm{H}) ;{ }^{13} \mathrm{C} \mathrm{NMR}\left(\mathrm{CDCl}_{3}, 75.5 \mathrm{MHz}\right): \delta 191.00,146.5,136.5$, $133.53,130.09,128.64,127.18,60.32,32.48,27.88,23.65$; MS (EI): 41 (13), 57 (34), 77 (25), $105(100), 312\left(\mathrm{M}^{+}, 0.08\right)$. Exact mass calcd. for $\mathrm{C}_{15} \mathrm{H}_{20} \mathrm{O}_{3} \mathrm{~S}_{2} \mathrm{H}^{+}: 313.0932$. Observed: 313.0930 .

Benzoylmethyl thiobenzoate 9e. Prepared by the reaction of benzoyl chloride (0.5 equiv.) with 8: $-70^{\circ} \mathrm{C}$ to $25^{\circ} \mathrm{C}, 8 \mathrm{~h}$ at $25^{\circ} \mathrm{C} ; 85 \%$ yield; purified by flash chromatography (hexane:ether, 10:1). IR (neat): 3067 (br s), 1669 (s), 1598 (m), 1582 (m), $1449(\mathrm{~m}), 1285(\mathrm{~m}), 1275(\mathrm{~m}), 1262$ (br s), $1206(\mathrm{~s}), 1176(\mathrm{~s}), 1000(\mathrm{br} \mathrm{s}), 911(\mathrm{~s}) \mathrm{cm}^{-1} ; 1_{\mathrm{H} \mathrm{NMR}}\left(\mathrm{CDCl}_{3}, 300 \mathrm{MHz}\right): 88.1-8.0(\mathrm{~m}$. 4H), 7.65-7.55 (m, 2H), 7.54-7.45 (m, 4H), 4.60 (s, 2H); ${ }^{3} \mathrm{C} \mathrm{NMR}\left(\mathrm{CDCl}_{3}, 75.5 \mathrm{MHz}\right):$ ह $193.29,190.24,136.42,135.82,133.66,133.60,128.74,128.66,128.52,127.44,36.55$; MS (EI): $77(34), 105(100), 256\left(2.68, \mathrm{M}^{+}\right)$. Exact mass calcd. for $\mathrm{C}_{15} \mathrm{H}_{12} \mathrm{O}_{2} \mathrm{~S}: 256.0558$. Observed: 256.0558 .

Tributylstannylmethyl thiobenzoate 9 . Prepared by the reaction of 8 with tributylin chloride $(0.5$ equiv.): $-70^{\circ} \mathrm{C}$ to $-20 \mathrm{C}, 8 \mathrm{~h} ; 64 \%$ yield; purified by flash chromatography (hexane:ether, $20: 1$ ). IR (neat): 2955 (s), 2933 (s), 2870 (s), 2852 (s), 1662 (s), 1646 (s), 1580 (m), 1477 (m), 1452

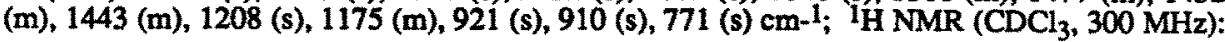


8 7.96-7.92 (m, 2H), 7.55-7.50 (m, 1H), 7.44-7.23 (m, 2H), $2.20(\mathrm{~s}, 2 \mathrm{H}), 1.56-1.45(\mathrm{~m}, 6 \mathrm{H})$, $1.35-1.23(\mathrm{~m}, 6 \mathrm{H}), 1.07-0.93(\mathrm{~m}, 6 \mathrm{H}), 0.87(\mathrm{t}, 9 \mathrm{H}, j=3.9 \mathrm{~Hz}) ;{ }^{13 \mathrm{C} N M R}(\mathrm{CDCl}, 75.5$ MHz): $\delta$ 193.7, 137.53, 132.84, 128. 49, 127.00, 28.99, 27.24, 13.60, 10.27, 4.71; MS (EI):

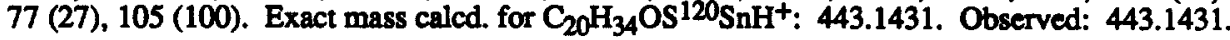

\section{Analytical data for products 10a-i.CTable I).}

2-Nonynyl phenyl sulfide 10a. Prepared by the reaction of 7a with 1-bromooctyne (0.7 equiv.): $-70^{\circ} \mathrm{C}$ to $-60^{\circ} \mathrm{C}, 15 \mathrm{~h} ; 70 \%$ yield; purified by flash chromatography (hexane:ether $\left.24: 1\right)$. IR (neat): 3059 (s), 2953 (br s), 2869 (s), 2200 (s), 1713 (s), 1670 (s), 1583 (s), 1479 (m), 1053 (m), $740(\mathrm{~s}), 689(\mathrm{~s}) \mathrm{cm}^{-1}$; ${ }_{\mathrm{H} ~ N M R}\left(\mathrm{CDCl}_{3}, 300 \mathrm{MHz}\right): 87.48-7.4(\mathrm{~m}, 2 \mathrm{H}), 7.35-7.2 \mathrm{(m}$, $3 \mathrm{H}), 3.6(\mathrm{~s}, 2 \mathrm{H}), 2.2-2.1(\mathrm{~m}, 2 \mathrm{H}), 1.5-1.3(\mathrm{~m}, 8 \mathrm{H}), 0.9(\mathrm{t}, 3 \mathrm{H}, J=6.2 \mathrm{~Hz}) ;{ }^{13} \mathrm{C} \mathrm{NMR}\left(\mathrm{CDCl}_{3}\right.$, $75.5 \mathrm{MHz}): d 136.0,129.7,128.5,126.2,84.0,75.5,31.1,28.5,28.3,23.0,22.3,18.6,13.8$; MS (EI): 39 (57), 41 (100), 53 (45), 67 (34), 81 (42), 91 (13), 109 (25), 129 (20), 147 (48), 161 (26), 232 (75). Exact mass calcd. for $\mathrm{C}_{15} \mathrm{H}_{20} \mathrm{~S}$ : 232.1285. Observed: 232.1276.

1-Phenyl-2-phenylthio-1-ethanol 10b. Prepared by the reaction of $7 \mathrm{a}$ with benzaldehyde $(0.5$ equiv.) in the presence of $\mathrm{BF}_{3} \cdot \mathrm{OEt}_{2}$ (1 equiv.): $-70^{\circ} \mathrm{C}$ to $0^{\circ} \mathrm{C} ; 36 \mathrm{~h} ; 71 \%$ yield; purified by flash chromatography (hexane:ethyl acetate, 9:1). IR (neat): 3389 (br), 3059 (s), 3030 (s), 2920 (s),

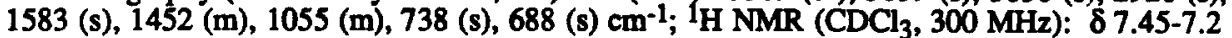
$(\mathrm{m}, 10 \mathrm{H}), 4.7$ (dd, $1 \mathrm{H}, J=6.5 \mathrm{~Hz}, J=3.7 \mathrm{~Hz}$ ), 3.3 (dd, $1 \mathrm{H}, J=12.5 \mathrm{~Hz}, J=3.7 \mathrm{~Hz}$ ), 3.15-3.0 $(\mathrm{m}, 1 \mathrm{H}), 2.9$ (br s, $1 \mathrm{H}) ;{ }^{13} \mathrm{C} \mathrm{NMR}\left(\mathrm{CDCl}_{3}, 75.5 \mathrm{MHz}\right)$ : 8 142.2, 135.2, 130.0, 128.9, 128.3, 127.7, 126.5, 125.7, 71.9, 43.8; MS (EI): 39 (17), 45 (40), 51 (31), 77 (40), 79 (48), 107 (35), 124 (100), 230 (6). Exact mass calcd. for $\mathrm{C}_{14} \mathrm{H}_{14}$ SO: 230.0765 . Observed: 230.0768 .

tert-Butyl 2-((2-phenylthio)propyl)-2-propenoate 10c. Prepared by the reaction of $7 \mathrm{~b}$ with tert-butyl $\alpha$-(bromomethyl)acrylate $\left(0.7\right.$ equiv.): $-70^{\circ} \mathrm{C}$ to $0^{\circ} \mathrm{C}, 0.5 \mathrm{~h} ; 87 \%$ yield, purified by flash chromatography (hexane:ether, 19:1). IR (neat): 3025 (s), 2976 (s), 2927 (br s), 1708 (s), $1629(\mathrm{~s}), 1584(\mathrm{~s}), 1438(\mathrm{~m}), 1339(\mathrm{~m}), 1147(\mathrm{~m}), 946(\mathrm{~s}), 850(\mathrm{~s}), 747(\mathrm{~s}), 692(\mathrm{~s}) \mathrm{cm}^{-1}$; ${ }_{\mathrm{H}}$ NMR $\left(\mathrm{CDCl}_{3}, 300 \mathrm{MHz}\right): \delta$ 7.46-7.38 (m, 2H), 7.3-7.15 (m, 3H), 6.15 (s, 1H), 5.5 (s, 1H), $3.5-3.4(\mathrm{~m}, 1 \mathrm{H}), 2.68(\mathrm{dd}, 1 \mathrm{H}, J=12.0 \mathrm{~Hz} J=6.0 \mathrm{~Hz}), 2.42(\mathrm{dd}, 1 \mathrm{H}, J=12.0 \mathrm{~Hz}, J=6.0$ $\mathrm{Hz}), 1.5(\mathrm{~s}, 9 \mathrm{H}), 1.27(\mathrm{~d}, 3 \mathrm{H}, J=6.0 \mathrm{~Hz}) ;{ }^{3} \mathrm{C}$ NMR $\left(\mathrm{CDCl}_{3}, 75.5 \mathrm{MHz}\right): \delta 165.8,139.2$, 135.3, 131.8, 128.5, 126.5, 126.1, 80.4, 41.7, 39.7, 27.9, 20.5; MS (EI): 39 (33), 41 (68), 49 (20), 57 (61), 67 (25), 110 (34), 111 (49), 137 (100), 175 (8), 205 (15), 222 (8), 278 (10). Exact mass calcd. for $\mathrm{C}_{16} \mathrm{H}_{22} \mathrm{SO}_{2}: 278.1340$. Observed: 278.1339 .

3-((1-Phenylthio )buryl)-cyclohexanone 10d. Prepared by the reaction of $7 \mathrm{c}$ with cyclohexenone ( 0.6 equiv.) in the presence of $\mathrm{Me}_{3} \mathrm{SiCl}\left(1.2\right.$ equiv.); $-70^{\circ} \mathrm{C}$ to $25^{\circ} \mathrm{C}, 12 \mathrm{~h} ; 78 \%$ yield; purified by flash chromatography (hexane:ethylacetate, 5:1); obtained as a 1:1 mixture of diastereomers. IR (neat): 3057 (s), 2920 (br s), 1712 (s), 1582 (s), 1422 (m), 1269 (m), 1067 (m), 1025 (s), 743 (s), $701(\mathrm{~s}) \mathrm{cm}^{-1}$; $1_{\mathrm{H} ~ N M R}\left(\mathrm{CDCl}_{3}, 300 \mathrm{MHz}\right): 87.4-7.32(\mathrm{~m}, 2 \mathrm{H}), 7.3-7.15(\mathrm{~m}, 3 \mathrm{H}), 3.1-2.98$ (m, 1H), 2.56-2.18 (m, 4H), 2.14-2.0 (m, 2H), 1.98-1.87 (m, 1H), 1.7-1.4 (m, 6H), 0.96-0.86 $(\mathrm{m}, 3 \mathrm{H}) ;{ }^{13} \mathrm{C}$ NMR $\left(\mathrm{CDCl}_{3}, 75.5 \mathrm{MHz}\right): \delta 210.8,210.7,136.2,131.18,131.15,128.6,126.3$, $55.1,54.7,45.6,44.1,43.0,42.7,41.07,35.0,34.3,28.3,26.9,24.8,20.5,20.4,13.6 ;$ MS (EI): $41(88), 55(100), 69(36), 97(19), 110(46), 123(34), 165(23), 262(21)$. Exact mass calcd. for $\mathrm{C}_{16} \mathrm{H}_{22} \mathrm{SO}: 262.1391$. Observed: 262.1380 .

3-(1-Phenylthiobutyl)-2-cyclohexen-1-one 10e. Prepared by the reaction of $7 \mathrm{c}$ with 3-iodo-2-cyclohexen-1-one ( 0.6 equiv.); $-70^{\circ} \mathrm{C}$ to r.t., $12 \mathrm{~h} ; 88 \%$ yield; purified by flash chromatography (hexane:ethyl acetate, 4:1). IR (neat): 3057 (s), 2956 (br s), 1767 (s), 1618 (s), 1582 (s), 1438 (m), 1346 (m), 1254 (s), 1169 (s), 1133 (s), 1090 (s), 964 (s), 887 (s), 751 (s), $702(\mathrm{~s}) \mathrm{cm}^{-1} ;{ }^{1} \mathrm{H}$ NMR $\left(\mathrm{CDCl}_{3}, 300 \mathrm{MHz}\right): \delta 7.38-7.3(\mathrm{~m}, 2 \mathrm{H}), 7.29-7.2(\mathrm{~m}, 3 \mathrm{H}), 5.55(\mathrm{~s}, 1 \mathrm{H})$, $3.68(\mathrm{t}, 1 \mathrm{H}, J=6.2 \mathrm{~Hz}), 2.62-2.52(\mathrm{~m}, 1 \mathrm{H}), 2.35-2.25(\mathrm{~m}, 3 \mathrm{H}), 2.03-1.82(\mathrm{~m}, 2 \mathrm{H}), 1.8-1.6$ $(\mathrm{m}, 2 \mathrm{H}), 1.52-1.35(\mathrm{~m}, 2 \mathrm{H}), 0.95(\mathrm{t}, 3 \mathrm{H}, J=6.0 \mathrm{~Hz}) ;{ }^{13} \mathrm{C} \mathrm{NMR}\left(\mathrm{CDCl}_{3}, 75.5 \mathrm{MHz}\right): \delta 198.5$, $162.7,133.3,132.8,128.4,127.4,126.5,55.6,37.2,33.7,24.9,22.3,20.4,13.3$; MS (EI): $41(30), 49$ (37), $55(20), 67(27), 81$ (50), $110(33), 133(29), 151(100), 189$ (12), 203 (11), 217 (11), 260 (74). Exact mass calcd. for $\mathrm{C}_{16} \mathrm{H}_{20} \mathrm{SO}$ : 260.1234 . Observed: 260.1228.

Phenyl (1-Phenylthio)butyl ketone 10f. Prepared by the reaction of $7 \mathrm{c}$ with benzoyl chloride $(0.6$ equiv.); $-70^{\circ} \mathrm{C}$ to $-10^{\circ} \mathrm{C}, 12 \mathrm{~h}, 93 \%$ yield; purified by flash chromatography (hexane:ethyl acetate, 4:1). IR (neat): 3059 (s), 2958 (s), 2932 (s), 2872 (s), 1678 (s), 1596 (s), 1581 (s), 1469 (m), 
1247 (m), 1025 (s), 965 (s), 748 (s), 689 (s) $\mathrm{cm}^{-1}$; ${ }^{1} \mathrm{H} \mathrm{NMR}\left(\mathrm{CDCl}_{3}, 300 \mathrm{MHz}\right): \delta 9.95-7.9$ (m, $2 \mathrm{H}), 7.6-7.2(\mathrm{~m}, 8 \mathrm{H}), 4.48(\mathrm{t}, 1 \mathrm{H}, J=6.5 \mathrm{~Hz}), 2.06-1.95(\mathrm{~m}, 1 \mathrm{H}), 1.9-1.78(\mathrm{~m}, 1 \mathrm{H}), 1.6-1.4$ $(\mathrm{m}, 2 \mathrm{H}), 0.94(\mathrm{t}, 3 \mathrm{H}, J=6.5 \mathrm{~Hz}) ;{ }^{13} \mathrm{C}$ NMR $\left(\mathrm{CDCl}_{3}, 75.5 \mathrm{~Hz}\right): \delta 195.8,136.2,134.1,132.7$, $128.7,128.69$, 128.65, 128.5, 128.2, 51.3, 33.1, 20.4, 13.7; MS (EI): 45 (12), 55 (24), 77 (48), 105 (55), 123 (100), 165 (94), 270 (30). Exact mass calcd. for $\mathrm{C}_{17} \mathrm{H}_{18}$ SO: 270.1078. Observed: 270.1078 .

4-Oxo-4-phenyl-(3-phenylthio)butane nitrile 10g. Prepared by the reaction of $7 \mathrm{~d}$ with benzoyl chloride $\left(0.5\right.$ equiv.); $-70^{\circ} \mathrm{C}$ to $-10^{\circ} \mathrm{C}, 15 \mathrm{~h}, 79 \%$ yield; purified by flash chromatography (hexane:ethyl acetate, 4:1). IR (neat): 3074 (s), 2932 (s), 2250 (s), 1748 (s), 1644 (s), 1574 (s), 1439 (m), 1315 (m), 1025 (s), 900 (s), 750 (s), $693(\mathrm{~s}) \mathrm{cm}^{-1} ;{ }^{1} \mathrm{H}$ NMR (CDCl, $\left.300 \mathrm{MHz}\right): \delta$ $7.98(\mathrm{~d}, 2 \mathrm{H}, J=7.3 \mathrm{~Hz}), 7.68-7.26(\mathrm{~m}, 8 \mathrm{H}), 4.72(\mathrm{t}, 1 \mathrm{H}, j=6.2 \mathrm{~Hz}$ ), 2.85 (dd, $2 \mathrm{H}, J=6.7$ $\mathrm{Hz}, J=9 \mathrm{~Hz}) ;{ }^{13} \mathrm{C} \mathrm{NMR}\left(\mathrm{CDCl}_{3}, 75.5 \mathrm{MHz}\right): \delta 192.0,135.7,134.2,133.6,129.8,129.2$, 128.67, 128.61, 128.2, 117.6, 46.6, 19.4; MS (EI): 41 (31), 42 (35), 43 (100), 51 (25), 57 (11), 77 (45), 105 (97), 109 (9), 267 (5). Exact mass calcd. for $\mathrm{C}_{16} \mathrm{H}_{13} \mathrm{SNO}$ : 267.0717. Observed: 267.0709 .

5-Butyl-3-phenylthio-hexane nitrile 10h. Prepared by the reaction of 7d with (2-bromomethyl) hexane $\left(0.6\right.$ equiv.): $-78{ }^{\circ} \mathrm{C}$ to $0{ }^{\circ} \mathrm{C}, 30 \mathrm{~min} ., 75 \%$ yield; purified by flash chromatography (hexane:ether, 6:4). IR (neat): 3074 (s), 2929 (br s), 2859 (s), 2248 (s), 1640 (s), 1417 (m), $1284(\mathrm{~m}), 900(\mathrm{~s}) \mathrm{cm}^{-1}$; ${ }_{\mathrm{H}} \mathrm{NMR}\left(\mathrm{CDCl}_{3}, 300 \mathrm{MHz}\right): 87.56-7.48(\mathrm{~m}, 2 \mathrm{H}), 7.4-7.3(\mathrm{~m}, 3 \mathrm{H})$, $4.94(\mathrm{~d}, 2 \mathrm{H}, J=9.0 \mathrm{~Hz}), 3.46-3.36(\mathrm{~m}, 1 \mathrm{H}), 2.63-2.35(\mathrm{~m}, 4 \mathrm{H}), 2.06(\mathrm{t}, 2 \mathrm{H}, J=6.5 \mathrm{~Hz})$, $1.48-1.28(\mathrm{~m}, 4 \mathrm{H}), 0.93(\mathrm{t}, 3 \mathrm{H}, J=6.5 \mathrm{~Hz}) ;{ }^{3} \mathrm{C} \mathrm{NMR}\left(\mathrm{CDCl}_{3}, 75.5 \mathrm{MHz}\right): \delta 144.7,133.0$, $132.4,128.7,128.0,116.7,112.9,42.6,40.2,34.8,29.5,22.8,22.0,13.6$; MS (EI): 41 (100), 51 (24), 55 (49), 65 (27), 77 (22), $109(55), 120$ (30), 135 (19), 162 (79), 259 (20). Exact mass calcd. for $\mathrm{C}_{16} \mathrm{H}_{21} \mathrm{SN}: 259.1394$. Observed: 259.1391 .

3-(3-Oxo-1-cyclohexenyl)-(3-phenylthio)propane nitrile 10i. Prepared by the reaction of 7d with 3-iodo-2-cyclohexen-1-one ( 0.6 equiv.); $-78{ }^{\circ} \mathrm{C}$ to r.t., $12 \mathrm{~h}, 86 \%$ yield; purified by flash chromatography (hexane:ethyl acetate, 1:1). IR (neat): 3046 (s), 2932 (br s), 2249 (s), 1735 (s), $1673(\mathrm{~s}), 1426(\mathrm{~m}), 1265(\mathrm{~m}), 1030(\mathrm{~s}), 910(\mathrm{~s}) \mathrm{cm}^{-1} ;{ }^{1} \mathrm{H} \mathrm{NMR}\left(\mathrm{CDCl}_{3}, 300 \mathrm{MHz}\right): \delta 7.4-7.23$ $(\mathrm{m}, 5 \mathrm{H}), 5.5(\mathrm{~s}, 1 \mathrm{H}), 3.78(\mathrm{t}, 1 \mathrm{H}, J=6.5 \mathrm{~Hz}), 2.74-2.66(\mathrm{~m}, 2 \mathrm{H}), 2.48(\mathrm{~d}, 2 \mathrm{H}, J=6.5 \mathrm{~Hz})$, $2.38-2.2(\mathrm{~m}, 2 \mathrm{H}), 2.05-1.95(\mathrm{~m}, 2 \mathrm{H})$; ${ }^{13} \mathrm{C} \mathrm{NMR}\left(\mathrm{CDCl}_{3}, 75.5 \mathrm{MHz}\right): \delta 197.9,158.5,134.1$, $130.6,130.3,129.5,128.9,128.8,126.5,116.3,50.2,36.9,26.4,22.1,21.1$; MS (EI): 39 (57), 51 (34), $65(66), 79(48), 93(49), 110(100), 120(19), 147(26), 161(18), 189(14), 203$ (31), 217 (60), 257 (81). Exact mass calcd. for $\mathrm{C}_{15} \mathrm{H}_{15} \mathrm{SNO}$ : 257.0874. Observed: 257.0867 .

Ethyl 6-carboethoxy-4-phenylthio-6-heptenoate 10j. Prepared by the reaction of 7e with ethyl $\alpha$-(bromomethyl)acrylate $\left(0.6\right.$ equiv.): $-70^{\circ} \mathrm{C}$ to $0{ }^{\circ} \mathrm{C}, 0.5 \mathrm{~h}, 92 \%$ yield; purified by flash chromatography (hexane:ether, 4:1). IR (neat): 3040 (s), 2935 (br s), 1721 (s), 1629 (s), 1583 (s), 1439 (m), 1302 (m), 1194 (m), 1026 (s), 950 (s), 818 (s), $744(\mathrm{~s}), 692(\mathrm{~s}) \mathrm{cm}^{-1}$; 1 H NMR $\left(\mathrm{CDCl}_{3}, 300 \mathrm{MHz}\right): 87.45-7.4(\mathrm{~m}, 2 \mathrm{H}), 7.3-7.15(\mathrm{~m}, 3 \mathrm{H}), 6.28(\mathrm{~s}, 1 \mathrm{H}), 5.65(\mathrm{~s}, 1 \mathrm{H}), 4.18(\mathrm{q}$, $2 \mathrm{H}, J=6.5 \mathrm{~Hz}), 4.1(\mathrm{q}, 2 \mathrm{H}, J=6.5 \mathrm{~Hz}), 3.44-3.36(\mathrm{~m}, 1 \mathrm{H}), 2.71-2.5(\mathrm{~m}, 4 \mathrm{H}), 2.09-2.0(\mathrm{~m}$, $1 \mathrm{H}), 1.8-1.7(\mathrm{~m}, 1 \mathrm{H}), 1.28(\mathrm{t}, 3 \mathrm{H}, J=6.5 \mathrm{~Hz}), 1.24(\mathrm{t}, 3 \mathrm{H}, J=6.5 \mathrm{~Hz}) ;{ }^{13} \mathrm{C}$ NMR $\left(\mathrm{CDCl}_{3}\right.$, 75.5 MHz): \& 172.7, 166.4, 137.5, 134.6, 131.8, 128.6, 127.4, 126.6, 60.4, 60.0, 46.8, 38.3, $31.3,29.0,14.0,13.9$; MS (EI): 41 (31), 49 (45), 79 (41), 84 (30), 109 (34), $135(62), 149$ (100), 177 (40), 181 (31), $223(26), 291(10), 336$ (7). Exact mass calcd. for $\mathrm{C}_{18} \mathrm{H}_{24} \mathrm{SO}_{4}$ : 336.1395. Observed: 336.1396.

Breparation of 3-carboethoxy and 3-carbo tert-butoxy-tetrahydrothiophene 11a and 11b. A solution of the thicester $9 \mathrm{a}(530 \mathrm{mg}, 2 \mathrm{mmol})$ in $10 \mathrm{~mL}$ of dry ethanol was added under argon at $25^{\circ} \mathrm{C}$ to an ethanol solution of sodium ethoxide $(2.67 \mathrm{mmol})$ (prepared by the reaction of $\mathrm{NaH}$ ( 80 $\mathrm{mg}, 2.67 \mathrm{mmol}, 80 \%$ in oil) with ethanol). GLC analysis of the reaction mixture show the completion of the reaction after $0.5 \mathrm{~h}$ of stiming. The solvent was evaporated and the crude residue was dissolved in ether washed with a saturated aqueous ammonium chloride solution ( $50 \mathrm{~mL}$ ), a brine solution $(30 \mathrm{~mL})$, dried over magnesium sulfate, and filtered. After evaporation of the solvent, the crude residue was purified by flash chromatography to afford 11 a as the sole product (solvent: ethyl acetate:hexane, 1:99); $225 \mathrm{mg}, 67 \%$ yield. The same procedure was used to prepare 11b starting from $9 b$. 
3-Carboethoxy tetrahydrothiophene 11. IR (neat): 2979 (s), 2961 (s), 2937 (s), 2907 (m), 2867 (m), 1732 (s), 1462 (m), 1443 (m), 1391 (m), 1370 (m), 1347 (m), $1312(\mathrm{~m}), 1276(\mathrm{~m}), 1258$ (s), 1225 (s), 1185 (s), 1156 (s), $1160(\mathrm{~m}), 1071$ (s), 1032 (m) cm-1, ${ }_{\mathrm{H}} \mathrm{NMR}$ (CDCl, 300 MHz): $\delta 4.14(\mathrm{q}, 2 \mathrm{H}, J=7.2 \mathrm{~Hz}), 3.05-3.02(\mathrm{~m}, 3 \mathrm{H}), 2.91-2.85(\mathrm{~m}, 2 \mathrm{H}), 2.28-2.13(\mathrm{~m}, 2 \mathrm{H})$, 1.25 (t, 3H, $J=7.2 \mathrm{~Hz}) ;{ }^{13} \mathrm{C} \mathrm{NMR}\left(\mathrm{CDCl}_{3}, 75.5 \mathrm{MHz}\right)$ : $\delta 173.18,60.94,33.99,33.51,30.74$, 14.20; MS (EI): 39 (14), 41 (18), 45 (52), 46 (10), 47 (16), 53 (16), 55 (11), 59 (15), 60 (13), 73 (32), 85 (48), $86(100), 87(59), 88(12), 101$ (14), 115 (17), $160(50), 161$ (71). Exact mass calcd. for $\mathrm{C}_{7} \mathrm{H}_{12} \mathrm{O}_{2} \mathrm{~S}$ : 160.0558 . Observed: 160.0553 .

3-Carbo tert-butoxy tetrahydrothiophene 11b. IR (neat): 3003 (m), 2977 (s), 2935 (s), 2866 (m), 1728 (s), 1478 (m), 1457 (m), 1392 (m), 1368 (s), 1279 (m), 1257 (m), 1230 (m), 1212 (m), 1151 (s), $847(\mathrm{~m}) \mathrm{cm}^{-1} ;{ }_{1}^{1} \mathrm{H} \mathrm{NMR}\left(\mathrm{CDCl}_{3}, 300 \mathrm{MHz}\right): 83.07-2.80(\mathrm{~m}, 5 \mathrm{H}), 2.24-2.11$ (m, 2H), $1.44(\mathrm{~s}, 9 \mathrm{H}) ;{ }^{13} \mathrm{C}$ NMR $\left(\mathrm{CDCl}_{3}, 75.5 \mathrm{MHz}\right): \delta 172.25,80.85,49.35,34.00,33.50$, 30.68, 28.04; MS (EI): 39 (30), 41 (73), $43(16), 45$ (41), 47 (11), 53 (13), 57 (100), 59 (12), 60 (13), $73(11), 85(25), 86(41), 87(48), 115(19), 131(10), 132(39), 188\left(M^{+}, 9.24\right)$. Exact mass calcd. for $\mathrm{C}_{9} \mathrm{H}_{16} \mathrm{O}_{2} \mathrm{~S}$ : 188.0871 . Observed: 188.0859 .

Analytical data for products 24a-24i Table III.

tert-Butyl (4-phenylthiobutyl) acrylate 24a. Prepared by the reaction of 20 with tert-butyl $\alpha$-(bromomethyl)acrylate $\left(0.7\right.$ equiv.): $-70^{\circ} \mathrm{C}$ to $0^{\circ} \mathrm{C}, 0.5 \mathrm{~h}, 87 \%$ yield; purified by flash chromatography (hexane:ether, 9:1). IR (neat): 3040 (s), 2930 (br s), 1711 (s), 1620 (s), 1480 (s), 1367 (s), $1152(\mathrm{~s}), 738$ (s), $\left.691(\mathrm{~s}) \mathrm{cm}^{-1} ; 1_{\mathrm{H} ~ N M R ~(C D C l}, 300 \mathrm{MHz}\right):$ \& $7.32-7.12(\mathrm{~m}$, SH), $6.04(\mathrm{~s}, 1 \mathrm{H}), 5.45(\mathrm{~s}, 1 \mathrm{H}), 2.94(\mathrm{t}, 2 \mathrm{H}, J=6.0 \mathrm{~Hz}), 2.25(\mathrm{t}, 2 \mathrm{H}, J=6.0 \mathrm{~Hz}), 1.72-1.58$ $(\mathrm{m}, 4 \mathrm{H}), 1.48(\mathrm{~s}, 9 \mathrm{H}) ;{ }^{13} \mathrm{C}$ NMR $\left(\mathrm{CDCl}_{3}, 75.5 \mathrm{MHz}\right): \delta 165.9,141.6,136.6,128.6,128.4$, $125.3,123.3,79.9,33.0,31.1,28.4,27.7,27.3$; MS (EI): 41 (41), 57 (100), 81 (26), $110(64)$, 123 (45), 190 (12), 219 (18), 236 (75), 292 (24). Exact mass calcd. for $\mathrm{C}_{17} \mathrm{H}_{24} \mathrm{SO}_{2}$ : 292.1497. Observed: 292.1494 .

3-(3-phenylthiopropyl)cyclohexanone 24b. Prepared by the reaction of 20 with cyclohex-2-en-1-one (0.6 equiv.) in the presence of $\mathrm{Me} S \mathrm{SiCl}\left(1.2\right.$ equiv.), $-70^{\circ} \mathrm{C}$ to $25^{\circ} \mathrm{C}, 8 \mathrm{~h}$, 84\% yield; purified by flash chromatography (hexane:ether, 4:1). IR (neat): 3057 (s), 2924 (br s), 2861 (s), $1716(\mathrm{~s}), 1583(\mathrm{~s}), 1447$ (m), $1312(\mathrm{~m}), 1226(\mathrm{~s}), 1092(\mathrm{~s}), 1025$ (s), 740 (s), 691 (s) $\mathrm{cm}^{-1}$; ${ }_{1} \mathrm{H}$ NMR $\left(\mathrm{CDCl}_{3}, 300 \mathrm{MHz}\right):$ o 7.35-7.24 (m, 4H), 7.2-7.12 (m, 1H), $2.9(\mathrm{t}, 2 \mathrm{H}, J=$ $6.5 \mathrm{~Hz}), 2.43-2.2(\mathrm{~m}, 3 \mathrm{H}), 2.08-1.25(\mathrm{~m}, 10 \mathrm{H}) ;{ }^{13} \mathrm{C} \mathrm{NMR}\left(\mathrm{CDCl}_{3}, 75.5 \mathrm{MHz}\right):{ }^{8} 210.5$, $136.3,128.8,128.7,128.5,125.5,47.6,41.0,38.2,35.1,33.4,30.8,25.9,24.8$; MS (EI): 41 (47), $55(26), 69(20), 97(82), 110(90), 123(51), 139(20), 152(29), 248(100)$. Exact mass calcd. for $\mathrm{C}_{15} \mathrm{H}_{20} \mathrm{SO}$ : 248.1234 . Observed: 248.1223 .

3-(3-Phenylthiopropyl)-2-cyclohexen-1-one 24c. Prepared by the reaction of 20 with 3-iodo-2-cyclohexen-1-one $\left(0.6\right.$ equiv.); $-70^{\circ} \mathrm{C}$ to $-25{ }^{\circ} \mathrm{C}, 12 \mathrm{~h}, 85 \%$ yield; purified by flash chromatography (hexane:ether, 4:1). IR (neat): 3042 (s), 2939 (br s), 1668 (s), 1624 (s), 1480 $(\mathrm{s}), 1438(\mathrm{~s}), 1325(\mathrm{~m}), 1254(\mathrm{~s}), 740(\mathrm{~s}) \mathrm{cm}^{-1} ;{ }_{1}^{1} \mathrm{H} \mathrm{NMR}\left(\mathrm{CDCl}_{3}, 300 \mathrm{MHz}\right): \delta$ $7.35-7.24(\mathrm{~m}$, $4 \mathrm{H}), 7.2-7.12(\mathrm{~m}, 1 \mathrm{H}), 5.86(\mathrm{~s}, 1 \mathrm{H}), 2.9(\mathrm{t}, 2 \mathrm{H}, J=6.0 \mathrm{~Hz}), 2.38-2.26(\mathrm{~m}, 4 \mathrm{H}), 2.22(\mathrm{t}, 2 \mathrm{H}, J$ $=6.0 \mathrm{~Hz}), 2.0-1.9(\mathrm{~m}, 2 \mathrm{H}), 1.85-1.75(\mathrm{~m}, 2 \mathrm{H}) ;{ }^{13} \mathrm{C} \mathrm{NMR}\left(\mathrm{CDCl}_{3}, 300 \mathrm{MHz}\right): \delta 198.4,164.2$, $135.5,128.7,128.3,125.7,125.4,36.7,36.0,32.5,25.7,22.0,19.7$; MS (EI): 41 (12), 49 (17), 53 (9), $65(10), 79(14), 84(14), 110(100), 123(38), 136(14), 168(4), 246(21)$. Exact mass calcd. for $\mathrm{C}_{15} \mathrm{H}_{18} \mathrm{SO}$ : 246.1078. Observed: 246.1066 .

Phenyl (3-phenylthiopropyl) ketone 24d. Prepared by the reaction of 20 with benzoyl chloride (0.6 equiv.); $-70{ }^{\circ} \mathrm{C}$ to $-20^{\circ} \mathrm{C}, 12 \mathrm{~h}, 80 \%$ yield; purified by flash chromatography (hexane:ether:dichloromethane, 9:2:1). IR (neat): 3050 (s), 2930 (br s), 1684 (s), 1612 (s), 1584 (s), $1348(\mathrm{~m}), 1274(\mathrm{~m}), 740(\mathrm{~s}), 690(\mathrm{~s}) \mathrm{cm}^{-1} ;{ }^{1} \mathrm{H}$ NMR $\left(\mathrm{CDCl}_{3}, 300 \mathrm{MHz}\right): \delta 7.98-7.92(\mathrm{~m}$, $2 \mathrm{H}), 7.6-7.15(\mathrm{~m}, 8 \mathrm{H}), 3.18(\mathrm{t}, 2 \mathrm{H}, J=6.5 \mathrm{~Hz}), 3.08(\mathrm{t}, 2 \mathrm{H}, J=6.5 \mathrm{~Hz}), 2.15-2.05(\mathrm{~m}, 2 \mathrm{H})$; ${ }^{13} \mathrm{C} \mathrm{NMR}\left(\mathrm{CDCl}_{3}, 75.5 \mathrm{MHz}\right): \delta 198.8,136.5,136.0,132.7,128.8,128.6,128.3,127.7$, 125.6, 36.7, 32.8, 23.2; MS (EI): 45(16), 51 (18), 77 (63), $105(54), 136(100), 147(50), 256$ (17). Exact mass calcd. for $\mathrm{C}_{16} \mathrm{H}_{16} \mathrm{OS}$ : 256.0921. Observed: 256.0915 .

(E)-Ethyl 6-Phenylthio-2-hexenoate 24e. Prepared by the reaction of 20 with ethyl propiolate ( 0.7 equiv.); $-60^{\circ} \mathrm{C}$ to $-50^{\circ} \mathrm{C}, 2 \mathrm{~h}, 95 \%$ yield; purified by flash chromatography (hexane:ether, 9:1). IR (neat): 3057 (s), 2935 (br s), 1718 (s), 1654 (s), 1439 (m), 1287 (m), 1200 (m), 1026 
(m), $739(\mathrm{~s}), 691(\mathrm{~s}) \mathrm{cm}^{-1}$; ${ }^{1} \mathrm{H}$ NMR (CDCl, $\left.300 \mathrm{MHz}\right): \delta 7.35-7.15(\mathrm{~m}, 5 \mathrm{H}), 6.95(\mathrm{td}, 1 \mathrm{H}, J=$ $7.0 \mathrm{~Hz}, J=1.7 \mathrm{~Hz}), 5.74(\mathrm{td}, 1 \mathrm{H}, J=15.6 \mathrm{~Hz}, J=1.6 \mathrm{~Hz}), 4.2(\mathrm{q}, 2 \mathrm{H}, J=7.1 \mathrm{~Hz}), 2.95(\mathrm{t}$, $2 \mathrm{H}, J=7.0 \mathrm{~Hz}), 2.35(\mathrm{qd}, 2 \mathrm{H}, J=7.7 \mathrm{~Hz}, J=1.5 \mathrm{~Hz}), 1.86-1.75(\mathrm{~m}, 2 \mathrm{H}), 1.3(\mathrm{t}, 3 \mathrm{H}, J=7.1$ $\mathrm{Hz}) ;{ }^{13} \mathrm{C}$ NMR $\left(\mathrm{CDCl}_{3}, 75.5 \mathrm{MHz}\right): \delta 166.2,147.4,136.0,129.3,128.7,125.9,122.0,60.0$, 33.0, 30.8, 27.3, 14.1; MS (EI): 41 (18), 45 (21), $49(100), 84$ (86), 99 (32), $110(43), 123$ (58), 141 (11), $176(5), 205$ (7), 250 (12). Exact mass calcd. for $\mathrm{C}_{14} \mathrm{H}_{18} \mathrm{O}_{2} \mathrm{~S}: 250.1027$. Observed: 250.1023 .

(Z)-Ethyl 3-carboethoxy-6-phenylthio-2-hexenoate 24f. Prepared by the reaction of 20 with diethyl acetylenedicarboxylate $(0.7$ equiv. $) ;-70^{\circ} \mathrm{C}$ to $-50^{\circ} \mathrm{C}, 1 \mathrm{~h}, 87 \%$ yield; purified by flash chromatography (hexane:ethyl acetate, 9:1). IR (neat): 3058 (s), 2938 (br s), 1723 (s), 1649 (s), $1594(\mathrm{~s}), 1466(\mathrm{~m}), 1346(\mathrm{~m}), 1219(\mathrm{~m}), 1069(\mathrm{~m}), 740(\mathrm{~s}), 692(\mathrm{~s}) \mathrm{cm}^{-1} ;{ }^{1} \mathrm{H}$ NMR $\left(\mathrm{CDCl}_{3}, 300\right.$ $\mathrm{MHz}):=87.4-1.15(\mathrm{~m}, 5 \mathrm{H}), 5.8(\mathrm{~s}, 1 \mathrm{H}), 4.26(\mathrm{q}, 2 \mathrm{H}, J=7.1 \mathrm{~Hz}), 4.19(\mathrm{q}, 2 \mathrm{H}, J=7.1 \mathrm{~Hz})$, $2.96(\mathrm{t}, 2 \mathrm{H}, J=7.1 \mathrm{~Hz}), 2.5(\mathrm{t}, 2 \mathrm{H}, J=7.3 \mathrm{~Hz}), 1.9-1.79(\mathrm{~m}, 2 \mathrm{H}), 1.36-1.2(\mathrm{~m}, 6 \mathrm{H}) ;{ }^{13} \mathrm{C}$ NMR (CDCl $3,75.5 \mathrm{MHz})$ : 8 168.1, 164.4, 148.6, 135.6, 129.3, 128.6, 125.9, 120.2, 61.0, 60.4, 32.8, 32.5, 26.2, 13.8, 13.7; MS (ED): 41 (20), 45 (38), 65 (22), $112(86), 123$ (96), 140 $(100), 149$ (32), $167(31), 186(32), 248$ (11), 277 (10), 322 (11). Exact mass calcd. for $\mathrm{C}_{17} \mathrm{H}_{22} \mathrm{O}_{4} \mathrm{~S}$ : 322.1238 . Observed: 322.1227 .

1-Methylthio-2-((3-phenylthio)propyl)-I-hexene 24g. Prepared in the following way: The

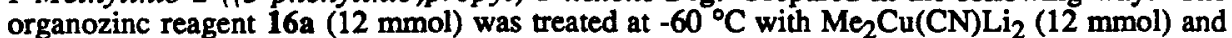
warmed to $0^{\circ} \mathrm{C}$, then cooled to $-60^{\circ} \mathrm{C}$ and 1 -methylthio-1-hexyne $(6 \mathrm{mmol}, 768 \mathrm{mg}$ ) was added. The reaction mixture was brought $0^{\circ} \mathrm{C}$ and stirred for $3 \mathrm{~h}$. After the usual workup, residue was purified by flash chromatography (hexane:ether, 49:1). IR (neat): 3074 (s), 3058 (s), 2923 (br s), $1585(\mathrm{~s}), 1438(\mathrm{~m}), 1298(\mathrm{~m}), 1092(\mathrm{~s}), 1025(\mathrm{~s}), 737(\mathrm{~s}), 690(\mathrm{~s}) \mathrm{cm}^{-1} ; \mathrm{H}$ NMR (CDCl, 300 $\mathrm{MHz}): \delta 7.36-7.14(\mathrm{~m}, 5 \mathrm{H}), 5.6(\mathrm{~s}, 1 \mathrm{H}), 2.92(\mathrm{t}, 2 \mathrm{H}, J=7.1 \mathrm{~Hz}), 2.25-2.15(\mathrm{~m}, 5 \mathrm{H}), 2.1(\mathrm{t}$, $2 \mathrm{H}, J=7.3 \mathrm{~Hz}), 1.8-1.7(\mathrm{~m}, 2 \mathrm{H}), 1.4-1.24(\mathrm{~m}, 4 \mathrm{H}), 0.9(\mathrm{t}, 3 \mathrm{H}, J=7.0 \mathrm{~Hz}) ;{ }^{13} \mathrm{C} \mathrm{NMR}\left(\mathrm{CDCl}_{3}\right.$, $75.5 \mathrm{MHz}): \delta 139.1,136.6,129.1,128.7,125.7,121.2,35.3,33.1,31.6,29.6,27.2,22.6$, 17.2, 13.9; MS (EI): 41 (32), 49 (100), 67 (48), $84(83), 123$ (51), $136(19), 155$ (12), 233 (70), 280 (4). Exact mass calcd. for $\mathrm{C}_{16} \mathrm{H}_{24} \mathrm{~S}_{2}$ : 280.1319. Observed: 280.1322.

2-Phenyl-5-phenylthio-1-nitropentane 24h. Prepared by the reaction of 20 with nitrostyrene $(0.7$ equiv.); $-70^{\circ} \mathrm{C}$ to $0^{\circ} \mathrm{C}, 1 \mathrm{~h}, 83 \%$ yield; purified by flash chromatography (hexane:ether, 48:2). IR (neat): 3029 (s), 2936 (br s), 1583 (s), 1550 (s), 1438 (m), 1379 (s), 1089 (s), 1025 (s), 763 (s), $692(\mathrm{~s}) \mathrm{cm}^{-1}$; ${ }^{1} \mathrm{H} \mathrm{NMR}\left(\mathrm{CDCl}_{3}, 300 \mathrm{MHz}\right): 87.35-7.1(\mathrm{~m}, 10 \mathrm{H}), 4.54(\mathrm{~d}, 2 \mathrm{H}, J=6.5 \mathrm{~Hz})$, $3.49-3.37(\mathrm{~m}, 1 \mathrm{H}), 2.92-2.75(\mathrm{~m}, 2 \mathrm{H}), 1.89-1.8(\mathrm{~m}, 2 \mathrm{H}), 1.6-1.45(\mathrm{~m}, 2 \mathrm{H})$; ${ }^{3} \mathrm{C} \mathrm{NMR}\left(\mathrm{CDCl}_{3}\right.$, $75.5 \mathrm{MHz}$ ): $\delta 138.7,136.0,129.0,128.77,128.70,127.4,127.3,125.7,80.5,43.7,33.1$, 31.5, 26.1; MS (EI): 45 (23), 65 (11), 77 (14), 91 (44), 109 (20), 117 (20), $123(30), 136$ (18), $145(100), 255(10), 301$ (5). Exact mass calcd. for $\mathrm{C}_{17} \mathrm{H}_{19} \mathrm{NO}_{2} \mathrm{~S}$ : 301.1136. Observed: 301.1131 .

4-Phenyl-7-phenylthio-2-heptanone 24i. Prepared by the reaction of 20 with benzylideneacetone (0.7 equiv.) in the presence of $\mathrm{Me}_{3} \mathrm{SiCl}\left(1.5\right.$ equiv.); $-70^{\circ} \mathrm{C}$ to $-10^{\circ} \mathrm{C}, 15 \mathrm{~h}, 81 \%$ yield; purified by flash chromatography (hexane:ether, 9:1). IR (neat): 3059 (s), 3027 (s), 2928 (br s), 1716 (s), $1583(\mathrm{~s}), 1452(\mathrm{~m}), 1356(\mathrm{~s}), 1248(\mathrm{~m}), 1161(\mathrm{~s}), 1092(\mathrm{~m}), 1025(\mathrm{~s}), 740(\mathrm{~s}), 692(\mathrm{~s}) \mathrm{cm}^{-1}$; $1_{\mathrm{H} ~ N M R}\left(\mathrm{CDCl}_{3}, 300 \mathrm{MHz}\right): \delta$ 7.32-7.1 (m, $\left.10 \mathrm{H}\right), 3.19-3.06(\mathrm{~m}, 1 \mathrm{H}), 2.9-2.75(\mathrm{~m}, 2 \mathrm{H})$, 2.74-2.62 (m, 2H), 2.0 (s, 3H), 1.86-1.62 (m, 2H), 1.6-1.4 (m, 2H); ${ }^{13} \mathrm{C} \mathrm{NMR} \mathrm{(CDCl} 3,75.5$ MHz): $\delta 207.0,143.7,136.5,128.9,128.6,128.3,127.2,126.3,125.5,50.6,40.9,35.0$, 33.4, 30.5, 26.6; MS (EI): 43 (100), $65(5), 77(7), 84(10), 91(16), 110(20), 123(25), 131$ (30), 147 (34), 240 (2), 298 (13). Exact mass calcd. for $\mathrm{C}_{19} \mathrm{H}_{22} \mathrm{OS}$ : 298.1391. Observed: 298.1393.

3-(3-phenylthiopropyl)cyclohexanone 24b. Prepared by the reaction of 20 with cyclohex-2-en-1-one ( 0.6 equiv.) in the presence of $\mathrm{Me}_{3} \mathrm{SiCl}\left(1.2\right.$ equiv.), $-70{ }^{\circ} \mathrm{C}$ to $25^{\circ} \mathrm{C}, 8 \mathrm{~h}$, $84 \%$ yield; purified by flash chromatography (hexane:ether, 4:1). IR (neat): 3057 (s), 2924 (br s), $2861(\mathrm{~s}), 1716(\mathrm{~s}), 1583(\mathrm{~s}), 1447(\mathrm{~m}), 1312(\mathrm{~m}), 1226(\mathrm{~s}), 1092(\mathrm{~s}), 1025(\mathrm{~s}), 740(\mathrm{~s}), 691$ (s) $\mathrm{cm}^{-1}$; ${ }_{\mathrm{H} ~ N M R}\left(\mathrm{CDCl}_{3}, 300 \mathrm{MHz}\right): \delta 8.35-7.24(\mathrm{~m}, 4 \mathrm{H}), 7.2-7.12(\mathrm{~m}, 1 \mathrm{H}), 2.9(\mathrm{t}, 2 \mathrm{H}, J=$ $6.5 \mathrm{~Hz}), 2.43-2.2(\mathrm{~m}, 3 \mathrm{H}), 2.08-1.25(\mathrm{~m}, 10 \mathrm{H}) ;{ }^{13} \mathrm{C} \mathrm{NMR}\left(\mathrm{CDCl}_{3}, 75.5 \mathrm{MHz}\right): \delta 210.5$, $136.3,128.8,128.7,128.5,125.5,47.6,41.0,38.2,35.1,33.4,30.8,25.9,24.8$; MS (EI): 41 
(47), $55(26), 69(20), 97(82), 110(90), 123(51), 139(20), 152(29), 248(100)$ ). Exact mass calcd. for $\mathrm{C}_{15} \mathrm{H}_{20} \mathrm{SO}$ : 248.1234 . Observed: 248.1223 .

3-(3-Phenylthiopropyl)-2-cyclohexen-1-one 24c. Prepared by the reaction of 20 with 3-iodo-2-cyclohexen-1-one ( 0.6 equiv.); $-70^{\circ} \mathrm{C}$ to $-25^{\circ} \mathrm{C}, 12 \mathrm{~h}, 85 \%$ yield; purified by flash chromatography (hexane:ether, 4:1). IR (neat): 3042 (s), 2939 (br s), 1668 (s), 1624 (s), 1480 (s), 1438 (s), 1325 (m), 1254 (s), 740 (s) cm cm $^{-1}{ }_{1} \mathrm{H}$ NMR $\left(\mathrm{CDCl}_{3}, 300 \mathrm{MHz}\right)$ : \& 7.35-7.24 (m, 4H), 7.2-7.12 (m, 1H), $5.86(\mathrm{~s}, 1 \mathrm{H}), 2.9(\mathrm{t}, 2 \mathrm{H}, J=6.0 \mathrm{~Hz}), 2.38-2.26(\mathrm{~m}, 4 \mathrm{H}), 2.22(\mathrm{t}, 2 \mathrm{H}, J$ $=6.0 \mathrm{~Hz}), 2.0-1.9(\mathrm{~m}, 2 \mathrm{H}), 1.85-1.75(\mathrm{~m}, 2 \mathrm{H}) ;{ }^{13} \mathrm{C} \mathrm{NMR}\left(\mathrm{CDCl}_{3}, 300 \mathrm{MHz}\right): \delta 198.4,164.2$, $135.5,128.7,128.3,125.7,125.4,36.7,36.0,32.5,25.7,22.0,19.7$; MS (EI): 41 (12), 49 (17), $53(9), 65(10), 79(14), 84(14), 110(100), 123(38), 136(14), 168(4), 246(21)$. Exact mass calcd. for $\mathrm{C}_{15} \mathrm{H}_{18} \mathrm{SO}: 246.1078$. Observed: 246.1066 .

Phenyl (3-phenylthiopropyl) ketone 24d. Prepared by the reaction of 20 with benzoyl chloride ( 0.6 equiv.); $-70^{\circ} \mathrm{C}$ to $-20^{\circ} \mathrm{C}, 12 \mathrm{~h}, 80 \%$ yield; purified by flash chromatography (hexane:ether:dichloromethane, 9:2:1). IR (neat): 3050 (s), 2930 (br s), 1684 (s), 1612 (s), 1584 (s), 1348 (m), $1274(\mathrm{~m}), 740$ (s), $690(\mathrm{~s}) \mathrm{cm}^{-1} ;{ }^{1} \mathrm{H} \mathrm{NMR}\left(\mathrm{CDCl}_{3}, 300 \mathrm{MHz}\right): \delta 7.98-7.92(\mathrm{~m}$, $2 \mathrm{H}), 7.6-7.15(\mathrm{~m}, 8 \mathrm{H}), 3.18(\mathrm{t}, 2 \mathrm{H}, J=6.5 \mathrm{~Hz}), 3.08(\mathrm{t}, 2 \mathrm{H}, J=6.5 \mathrm{~Hz}), 2.15-2.05(\mathrm{~m}, 2 \mathrm{H})$; ${ }_{13} \mathrm{C} \mathrm{NMR}\left(\mathrm{CDCl}_{3}, 75.5 \mathrm{MHz}\right): \delta 198.8,136.5,136.0,132.7,128.8,128.6,128.3,127.7$, 125.6, 36.7, 32.8, 23.2; MS (EI): 45 (16), 51 (18), $77(63), 105(54), 136(100), 147(50), 256$ (17). Exact mass calcd. for $\mathrm{C}_{16} \mathrm{H}_{16} \mathrm{OS}: 256.0921$. Observed: 256.0915.

(E)-Ethyl 6-Phenylthio-2-hexenoate 24e. Prepared by the reaction of 20 with ethyl propiolate ( 0.7 equiv.); $-60^{\circ} \mathrm{C}$ to $-50^{\circ} \mathrm{C}, 2 \mathrm{~h}, 95 \%$ yield; purified by flash chromatography (hexane:ether, 9:1). IR (neat): 3057 (s), 2935 (br s), 1718 (s), 1654 (s), 1439 (m), 1287 (m), $1200(\mathrm{~m}), 1026$ (m), 739 (s), 691 (s) cm cm $^{-1} 1_{\mathrm{H} M R}\left(\mathrm{CDCl}_{3}, 300 \mathrm{MHz}\right)$ : $87.35-7.15(\mathrm{~m}, 5 \mathrm{H}), 6.95(\mathrm{td}, 1 \mathrm{H}, J=$ $7.0 \mathrm{~Hz}, J=1.7 \mathrm{~Hz}), 5.74(\mathrm{td}, 1 \mathrm{H}, J=15.6 \mathrm{~Hz}, J=1.6 \mathrm{~Hz}), 4.2(\mathrm{q}, 2 \mathrm{H}, J=7.1 \mathrm{~Hz}), 2.95(\mathrm{t}$, $2 \mathrm{H}, J=7.0 \mathrm{~Hz}), 2.35(\mathrm{qd}, 2 \mathrm{H}, J=7.7 \mathrm{~Hz}, J=1.5 \mathrm{~Hz}), 1.86-1.75(\mathrm{~m}, 2 \mathrm{H}), 1.3(\mathrm{t}, 3 \mathrm{H}, J=7.1$ $\mathrm{Hz}) ;{ }^{13} \mathrm{C} \mathrm{NMR}\left(\mathrm{CDCl}_{3}, 75.5 \mathrm{MHz}\right): \delta 166.2,147.4,136.0,129.3,128.7,125.9,122.0,60.0$, 33.0, 30.8, 27.3, 14.1; MS (EI): 41 (18), $45(21), 49$ (100), 84 (86), 99 (32), $110(43), 123$ (58), 141 (11), $176(5), 205$ (7), 250 (12). Exact mass calcd. for $\mathrm{C}_{14} \mathrm{H}_{18} \mathrm{O}_{2} \mathrm{~S}: \quad 250.1027$. Observed: 250.1023.

(Z)-Ethyl 3-carboethoxy-6-phenylthio-2-hexenoate 24f. Prepared by the reaction of 20 with diethyl acetylenedicarboxylate $\left(0.7\right.$ equiv.); $-70^{\circ} \mathrm{C}$ to $-50^{\circ} \mathrm{C}, 1 \mathrm{~h}, 87 \%$ yield; purified by flash chromatography (hexane:ethyl acetate, 9:1). IR (neat): 3058 (s), 2938 (br s), 1723 (s), 1649 (s), $1594(\mathrm{~s}), 1466(\mathrm{~m}), 1346(\mathrm{~m}), 1219(\mathrm{~m}), 1069(\mathrm{~m}), 740(\mathrm{~s}), 692(\mathrm{~s}) \mathrm{cm}^{-1} ;{ }_{\mathrm{H}} \mathrm{H}^{\mathrm{N} M R}\left(\mathrm{CDCl}_{3}, 300\right.$ $\mathrm{MHz}): \delta 7.4-7.15(\mathrm{~m}, 5 \mathrm{H}), 5.8(\mathrm{~s}, 1 \mathrm{H}), 4.26(\mathrm{q}, 2 \mathrm{H}, J=7.1 \mathrm{~Hz}), 4.19(\mathrm{q}, 2 \mathrm{H}, J=7.1 \mathrm{~Hz})$, $2.96(\mathrm{t}, 2 \mathrm{H}, J=7.1 \mathrm{~Hz}), 2.5(\mathrm{t}, 2 \mathrm{H}, J=7.3 \mathrm{~Hz}), 1.9-1.79(\mathrm{~m}, 2 \mathrm{H}), 1.36-1.2(\mathrm{~m}, 6 \mathrm{H}) ; 13 \mathrm{C}$ NMR $\left(\mathrm{CDCl}_{3}, 75.5 \mathrm{MHz}\right): \delta 168.1,164.4,148.6,135.6,129.3,128.6,125.9,120.2,61.0$, $60.4,32.8,32.5,26.2,13.8,13.7$; MS (EI): $41(20), 45(38), 65(22), 112(86), 123(96), 140$ (100), 149 (32), 167 (31), 186 (32), 248 (11), 277 (10), 322 (11). Exact mass calcd. for $\mathrm{C}_{17} \mathrm{H}_{22} \mathrm{O}_{4} \mathrm{~S}: 322.1238$. Observed: 322.1227 .

1-Methylthio-2-((3-phenylthio)propyl)-1-hexene 24g. Prepared in the following way: The organozinc reagent $16 \mathrm{a}(12 \mathrm{mmol})$ was treated at $-60^{\circ} \mathrm{C}$ with $\mathrm{Me}_{2} \mathrm{Cu}(\mathrm{CN}) \mathrm{Li}_{2}(12 \mathrm{mmol})$ and warmed to $0^{\circ} \mathrm{C}$, then cooled to $-60^{\circ} \mathrm{C}$ and 1 -methylthio-1-hexyne $(6 \mathrm{mmol}, 768 \mathrm{mg})$ was added. The reaction mixture was brought to $0{ }^{\circ} \mathrm{C}$ and stirred for $3 \mathrm{~h}$. After the usual workup, residue was, purified by flash chromatography (hexane:ether, 49:1). IR (neat): 3074 (s), 3058 (s), 2923 (br s), $1585(\mathrm{~s}), 1438(\mathrm{~m}), 1298(\mathrm{~m}), 1092(\mathrm{~s}), 1025(\mathrm{~s}), 737(\mathrm{~s}), 690(\mathrm{~s}) \mathrm{cm}^{-1}, \mathrm{H}_{\mathrm{H}} \mathrm{NMR}\left(\mathrm{CDCl}_{3}, 300\right.$ $\mathrm{MHz}): \delta 7.36-7.14(\mathrm{~m}, 5 \mathrm{H}), 5.6(\mathrm{~s}, 1 \mathrm{H}), 2.92(\mathrm{t}, 2 \mathrm{H}, J=7.1 \mathrm{~Hz}), 2.25-2.15(\mathrm{~m}, 5 \mathrm{H}), 2.1(\mathrm{t}$, $2 \mathrm{H}, J=7.3 \mathrm{~Hz}), 1.8-1.7(\mathrm{~m}, 2 \mathrm{H}), 1.4-1.24(\mathrm{~m}, 4 \mathrm{H}), 0.9(\mathrm{t}, 3 \mathrm{H}, J=7.0 \mathrm{~Hz}) ;{ }^{13} \mathrm{C} \mathrm{NMR}\left(\mathrm{CDCl}_{3}\right.$, $75.5 \mathrm{MHz}): \delta 139.1,136.6,129.1,128.7,125.7,121.2,35.3,33.1,31.6,29.6,27.2,22.6$, 17.2, 13.9; MS (EI): 41 (32), 49 (100), 67 (48), $84(83), 123$ (51), 136 (19), 155 (12), 233 (70), 280 (4). Exact mass calcd. for $\mathrm{C}_{16} \mathrm{H}_{24} \mathrm{~S}_{2}: 280.1319$. Observed: 280.1322 .

2-Phenyl-5-phenylthio-1-nitropentane 24h. Prepared by the reaction of 20 with nitrostyrene 0.7 equiv.); $-70^{\circ} \mathrm{C}$ to $0^{\circ} \mathrm{C}, 1 \mathrm{~h}, 83 \%$ yield; purified by flash chromatography (hexane:ether, $48: 2$ ). IR (neat): 3029 (s), 2936 (br s), $1583(\mathrm{~s}), 1550(\mathrm{~s}), 1438(\mathrm{~m}), 1379(\mathrm{~s}), 1089(\mathrm{~s}), 1025(\mathrm{~s}), 763$ (s), $692(\mathrm{~s}) \mathrm{cm}^{-1}$; ${ }^{1} \mathrm{H} \mathrm{NMR}\left(\mathrm{CDCl}_{3}, 300 \mathrm{MHz}\right): \delta 7.35-7.1(\mathrm{~m}, 10 \mathrm{H}), 4.54(\mathrm{~d}, 2 \mathrm{H}, J=6.5 \mathrm{~Hz})$, 
3.49-3.37 (m, 1H), 2.92-2.75 (m, 2H), 1.89-1.8 (m, 2H), 1.6-1.45 (m, 2H); $13 \mathrm{C}$ NMR $\left(\mathrm{CDCl}_{3}\right.$, $75.5 \mathrm{MHz}): \quad \delta 138.7,136.0,129.0,128.77,128.70,127.4,127.3,125.7,80.5,43.7,33.1$, 31.5, 26.1; MS (EI): 45 (23), 65 (11), 77 (14), 91 (44), 109 (20), 117 (20), $123(30), 136$ (18), $145(100), 255$ (10), 301 (5). Exact mass calcd. for $\mathrm{C}_{17} \mathrm{H}_{19} \mathrm{NO}_{2} \mathrm{~S}$ : 301.1136. Observed: 301.1131 .

4-Phenyl-7-phenylthio-2-heptanone 24i. Prepared by the reaction of 20 with benzylideneacetone (0.7 equiv.) in the presence of $\mathrm{Me}_{3} \mathrm{SiCl}\left(1.5\right.$ equiv.); $-70^{\circ} \mathrm{C}$ to $-10^{\circ} \mathrm{C}, 15 \mathrm{~h}, 81 \%$ yield; purified by flash chromatography (hexane:ether, 9:1). IR (neat): 3059 (s), 3027 (s), 2928 (br s), 1716 (s), $1583(\mathrm{~s}), 1452(\mathrm{~m}), 1356(\mathrm{~s}), 1248(\mathrm{~m}), 1161(\mathrm{~s}), 1092(\mathrm{~m}), 1025(\mathrm{~s}), 740(\mathrm{~s}), 692(\mathrm{~s}) \mathrm{cm}^{-1}$; ${ }_{\text {H NMR }}\left(\mathrm{CDCl}_{3}, 300 \mathrm{MHz}\right): \delta 7.32-7.1(\mathrm{~m}, 10 \mathrm{H}), 3.19-3.06(\mathrm{~m}, 1 \mathrm{H}), 2.9-2.75(\mathrm{~m}, 2 \mathrm{H})$, 2.74-2.62 (m, 2H), $2.0(\mathrm{~s}, 3 \mathrm{H}), 1.86-1.62(\mathrm{~m}, 2 \mathrm{H}), 1.6-1.4(\mathrm{~m}, 2 \mathrm{H}) ;{ }^{13} \mathrm{C} \mathrm{NMR}\left(\mathrm{CDCl}_{3}, 75.5\right.$ $\mathrm{MHz}): \delta 207.0,143.7,136.5,128.9,128.6,128.3,127.2,126.3,125.5,50.6,40.9,35.0$, 33.4, 30.5, 26.6; MS (EI): 43 (100), 65 (5), 77 (7), 84 (10), 91 (16), $110(20), 123(25), 131$ (30), 147 (34), 240 (2), 298 (13). Exact mass calcd. for $\mathrm{C}_{19} \mathrm{H}_{22} \mathrm{OS:}$ 298.1391. Observed: 298.1393.

5-Carboethoxy-5-hexenyl phenyl sulfoxide 25a. Prepared by the reaction of 21 with ethyl $\alpha$-(bromomethyl)acrylate ( 0.7 equiv.) $-70^{\circ} \mathrm{C}$ to $0^{\circ} \mathrm{C}, 0.5 \mathrm{~h}, 76 \%$ yield; purified by flash chromatography (hexane:ethyl acetate, 7:1). IR (neat): 3055 (s), 2936 (br s), 1712 (s), 1630 (s), $1407(\mathrm{~m}), 1258(\mathrm{~m}), 1161(\mathrm{~m}), 946(\mathrm{~s}), 750(\mathrm{~s}), 693(\mathrm{~s}) \mathrm{cm}^{-1} ;{ }^{1} \mathrm{H} \mathrm{NMR}\left(\mathrm{CDCl}_{3}, 300 \mathrm{MHz}\right): \delta$ 7.68-7.5 (m, 5H), $6.16(\mathrm{~s}, 1 \mathrm{H}), 5.52(\mathrm{~s}, 1 \mathrm{H}), 4.2(\mathrm{q}, 2 \mathrm{H}, J=7.1 \mathrm{~Hz}), 2.86(\mathrm{t}, 2 \mathrm{H}, J=7.0 \mathrm{~Hz})$, $2.3(\mathrm{t}, 2 \mathrm{H}, J=7.0), 1.9-1.55(\mathrm{~m}, 4 \mathrm{H}), 1.3(\mathrm{t}, 3 \mathrm{H}, J=6.5 \mathrm{~Hz}) ;{ }^{13} \mathrm{C} \mathrm{NMR}\left(\mathrm{CDCl}_{3}, 75.5 \mathrm{MHz}\right)$ : $\delta 166.4,143.6,139.6,130.4,128.7,124.4,123.5,60.1,56.5,31.0,27.1,21.2,13.8 ; \mathrm{MS}$ (EI): 41 (30), $81(100), 109(89), 126(43), 155(68), 168(6), 235(27), 263(32), 280(18)$ Exact mass calcd. for $\mathrm{C}_{15} \mathrm{H}_{20} \mathrm{O}_{3} \mathrm{~S}$ : 280.1133 . Observed: 280.1144 .

Phenyl (3-trimethylstannyl)propyl sulfoxide 25b. Prepared by the reaction of 21 with chlorotrimethylstannane ( 0.7 equiv.); $-70^{\circ} \mathrm{C}$ to $0{ }^{\circ} \mathrm{C}, 1 \mathrm{~h}, 90 \%$ yield; purified by flash chromatography (hexane:ether:dichloromethane, 6:2:2). IR (neat): 3040 (s), 2930 (br s), 1458 (s), $1100(\mathrm{~s}), 1044(\mathrm{~s}), 747(\mathrm{~s}) \mathrm{cm}^{-1} ;{ }^{1} \mathrm{H}$ NMR (CDCl, $\left.300 \mathrm{MHz}\right):$ 8 7.68-7.6 (m, 2H), 7.56-7.45 (m, 3H), 2.86-2.7 (m, 2H), 2.0-1.74 (m, 2H), 0.96-0.74 (m, 2H), 0.09 (s, 9H); ${ }^{13} \mathrm{C}$ NMR (CDCl 3 ; 75.5 MHz): $\delta$ 144.1, 130.6, 128.9, 123.7, 61.2, 19.7, 9.6, -10.4; MS (CI with methane): 91 (5), $111(9), 119(14), 136(8), 161(26), 163(44), 165(58), 185(15), 301(14)$, $313(58), 315(88), 317(100), 329(24), 331(39), 333[\mathrm{M}+\mathrm{H}]^{+}(45)$. Exact mass calcd. for $\mathrm{C}_{12} \mathrm{H}_{20}{ }^{120}$ SnSOH: 333.0335 . Observed: $333.0346[\mathrm{M}+\mathrm{H}]^{+}$.

5-Carboethoxy-5-hexenyl phenyl sulfone 26. Prepared by the reaction of 22 with ethyl $\alpha$-(bromomethyl)acrylate $\left(0.7\right.$ equiv.); $-70^{\circ} \mathrm{C}$ to $0{ }^{\circ} \mathrm{C}, 0.5 \mathrm{~h}, 88 \%$; purified by flash chromatography (hexane:ethyl acetate, 4:1). IR (neat): 3050 (s), 2941 (br s), 1715 (s), 1630 (s), $\left.1406(\mathrm{~m}), 1260(\mathrm{~m}), 1148(\mathrm{~m}), 916(\mathrm{~s}), 732(\mathrm{~s}), 690(\mathrm{~s}) \mathrm{cm}^{-1} ;{ }^{1} \mathrm{H} \mathrm{NMR}_{(\mathrm{CDCl}}, 300 \mathrm{MHz}\right): \delta$ $7.98-7.9(\mathrm{~m}, 2 \mathrm{H}), 7.7-7.54(\mathrm{~m}, 3 \mathrm{H}), 6.15(\mathrm{~s}, 1 \mathrm{H}), 5.5(\mathrm{~s}, 1 \mathrm{H}), 4.18(\mathrm{q}, 2 \mathrm{H}, J=7.0 \mathrm{~Hz}), 3.16$ $(\mathrm{t}, 2 \mathrm{H}, J=8.0 \mathrm{~Hz}), 2.3(\mathrm{t}, 2 \mathrm{H}, J=7.5 \mathrm{~Hz}), 1.8-1.7(\mathrm{~m}, 2 \mathrm{H}), 1.62-1.5(\mathrm{~m}, 2 \mathrm{H}), 1.3(\mathrm{t}, 3 \mathrm{H}, J=$ $7.0 \mathrm{~Hz}) ;{ }^{13} \mathrm{C} \mathrm{NMR}\left(\mathrm{CDCl}_{3}, 75.5 \mathrm{MHz}\right): \delta 166.3,139.4,138.8,133.2,128.8,127.5,124.6$, $60.2,55.5,30.8,26.7,21.8,13.8$; MS (CI with ammonia): $108(5), 136(41), 148$ (5), 202 (24), 234 (14), $243(15), 297[\mathrm{M}+\mathrm{H}]{ }^{+}(13), 314\left[\mathrm{M}+\mathrm{NH}_{4}\right]^{+}(100)$. Exact mass calcd. for $\mathrm{C}_{15} \mathrm{H}_{20} \mathrm{O}_{4} \mathrm{SH}: 297.1160$. Observed: 297.1161 .

Ethyl 4-tert-butylsulfonyl-4-pentenyl acrylate 27a. Prepared by the reaction of 23 with ethyl $\alpha$-(bromomethyl)acrylate $\left(0.7\right.$ equiv.); $-70^{\circ} \mathrm{C}$ to $0^{\circ} \mathrm{C}, 0.5 \mathrm{~h}, 90 \%$ yield; purified by flash chromatography (hexane:ethyl acetate, 8:2). IR (neat): 3048 (s), 2984 (br s), 1717 (s), 1640 (s), $1428(\mathrm{~m}), 1289(\mathrm{~s}), 1103(\mathrm{~m}), 1040(\mathrm{~s}), 980(\mathrm{~s}) \mathrm{cm}^{-1} ;{ }^{1} \mathrm{H} \mathrm{NMR}\left(\mathrm{CDCl}_{3}, 300 \mathrm{MHz}\right): \delta 6.22(\mathrm{~s}$, $1 \mathrm{H}), 6.16(\mathrm{~s}, 1 \mathrm{H}), 6.0(\mathrm{~s}, 1 \mathrm{H}), 5.56(\mathrm{~s}, 1 \mathrm{H}), 4.2(\mathrm{q}, 2 \mathrm{H}, J=7.5 \mathrm{~Hz}), 2.46(\mathrm{t}, 2 \mathrm{H}, J=7.5 \mathrm{~Hz})$, $2.35(\mathrm{t}, 2 \mathrm{H}, J=7.5 \mathrm{~Hz}), 1.85-1.74(\mathrm{~m}, 2 \mathrm{H}), 1.4(\mathrm{~s}, 9 \mathrm{H}), 1.3(\mathrm{t}, 3 \mathrm{H}, J=7.5 \mathrm{~Hz}) ; 13 \mathrm{C}$ NMR $\left(\mathrm{CDCl}_{3}, 75.5 \mathrm{MHz}\right): \delta 167.7,147.3,139.8,128.2,125.0,60.6,60.0,31.4,31.2,27.5,23.7$, 14.1; MS (CI with methane): 95 (5), $119(6), 136(5), 151$ (3), $169(20), 187$ (41), $197(14), 215$ (100), $233(38), 243(16), 261(10), 273(8), 289\left[\mathrm{M}+\mathrm{H}^{+}(52), 306[\mathrm{M}+\mathrm{NH}]^{+}(33)\right.$. Exact mass calcd. for $\mathrm{C}_{14} \mathrm{H}_{24} \mathrm{O}_{4} \mathrm{SH}$ : 289.1473. Observed: $289.1472[\mathrm{M}+\mathrm{H}]^{+}$. 
3-((3-tert-Butylsulfonyl)-3-butenyl)-2-cyclohexen-1-one 27b. Prepared by the reaction of 23 with 3-iodo-2-cyclohexen-1-one ( 0.7 equiv.); $-78^{\circ} \mathrm{C}$ to $-30^{\circ} \mathrm{C}, 23 \mathrm{~h}, 93 \%$ yield; purified by flash chromatography (hexane:ether:dichloromethane, 6:3:1). IR (neat): 3095 (s), 2991 (s), 2972 (s), 2925 (br s), $1663(\mathrm{~s}), 1623$ (s), $1477(\mathrm{~m}), 1265(\mathrm{~m}), 1132(\mathrm{~m}), 980(\mathrm{~s}), 750(\mathrm{~s}), 625(\mathrm{~s}) \mathrm{cm}^{-1}$; ${ }^{1} \mathrm{H}$ NMR $\left(\mathrm{CDCl}_{3}, 300 \mathrm{MHz}\right): \quad \delta 6.28(\mathrm{~s}, 1 \mathrm{H}), 6.0(\mathrm{~s}, 1 \mathrm{H}), 5.9(\mathrm{~s}, 1 \mathrm{H}), 2.7-2.52(\mathrm{~m}, 4 \mathrm{H}), 2.4-2.3$ $(\mathrm{m}, 4 \mathrm{H}), 2.06-1.98(\mathrm{~m}, 2 \mathrm{H}), 1.4(\mathrm{~s}, 9 \mathrm{H}) ;{ }^{13} \mathrm{C} \mathrm{NMR}\left(\mathrm{CDCl}_{3}, 75.5 \mathrm{MHz}\right): \delta 198.9,163.2$, 146.0, 129.0, 125.9, 59.9, 36.9, 36.7, 29.3, 29.2, 23.3, 22.2; MS (CI with methane and ammonia): 75 (4), 85 (6), 91 (6), 101 (5), 111 (17), 119 (35), 136 (51), 151 (19), 167 (4), 179 (5), $197(6), 215(17), 243(4), 271\left[\mathrm{M}+\mathrm{H}^{+}\right](100), 288\left[\mathrm{M}+\mathrm{NH}_{4}\right]^{+}(18)$. Exact mass calcd. for $\mathrm{C}_{14} \mathrm{H}_{22} \mathrm{O}_{3} \mathrm{SH}$ : 271.1367. Observed: $271.1361[\mathrm{M}+\mathrm{H}]^{+}$.

\section{Acknowledgments}

We thank the National Institutes of Health (GM 41908) and the National Science Foundation for the generous support of this work.

\section{REFERENCES AND NOTES}

1. (a) Corey, E.J.; Seebach, D. J. Org. Chem. 1966, 31, 4097; (b) Peterson, D.J. J. Org. Chem. 1967, 32, 1717; (c) Trost, B.M.; Keeley, D.; Bogdanowicz, M.J. J. Am. Chem. Soc. 1973, 95, 3068; (d) Seebach, D. Synthesis 1969, 17; (e) Grobel, B.-T.; Seebach, D. Synthesis 1977, 357; (f) Herrmann, J.L.; Richman, J.E.; Schlessinger, R.H. Tetrahedron Lett. 1973, 2599; (g) Seebach, D. Chem. Ber. 1972, 105, 487; (h) Oshima, K.; Takahashi, H.; Yamamoto, H.; Nozaki, H. J. Am. Chem. Soc. 1973, 95, 2694; (i) Seebach, D.; Corey, E.J.; Beck, A.K. Chem. Ber. 1974, 107, 367; (j) Ogura, K.; Yamashita, M.; Suzuki, M.; Tsuchihashi, G. Tetrahedron Lett. 1974, 3653; (k) Watanabe, Y.; Shiono, M.; Mukaiyama, T. Chem. Lett. 1975, 871; (l) Cohen, T.; Matz, J.R. Synth. Commun. 1980, 10, 311; (m) Cohen, T.; Weisenfeld, R.B. J. Org. Chem. 1979, 44, 3601; (n) Hirai, K.; Matsuda, H.; Kishida, Y. Tetrahedron Lett. 1971, 4359; (o) Hirai, K.; Kishida, Y. Tetrahedron Lett., 1972, 2743; (p) Meyers, A.I. Ford, M.E. J. Org. Chem. 1976, 41, 1735; (q) Wartski, L.; El Bouz, M.; Seyden-Penne, J.; Dumont, W.; Krief, A. Tetrahedron Lett. 1979, 1543; (r) Johnson, C.R.; Nakanishi, A.; Nakanishi, N.; Tanaka, K. Tetrahedron Lett. 1975, 2865; (s) Negishi, E.; Yoshida, T.; Silveira, A.; Chiou, B.L. J. Org. Chem. 1975, 40, 814; (t) Reitz, D.B.; Beak, P.; Farney, R.F.; Helmick, L.S. J. Am. Chem. Soc. 1978, 100, 5428; (u) Krief, A. Tetrahedron 1980, 36, 2531.

2. Achyutha Rao, S.; Tucker, C.E.; Knochel, P. Tetrahedron Lett. 1990, 31, 7575.

3. (a) Knochel, P.; Chou, T.-S.; Chen, H.G.; Yeh, M.C.P.; Rozema, M.J. J. Org. Chem. 1989, 54, 5202; (b) Chou, T.-S.; Knochel, P. J. Org. Chem. 1990, 55, 4791.

4. Iodomethylthiobenzoate was prepared by a Finkelstein reaction from the corresponding chloride ( $89 \%$ yield; see expereimental section) which has been prepared according to a literature procedure: Bodor, N.; Sloan, K.B.; Kaminski, J.J.; Shih, C.; Pogamy, S. J. Org. Chem. 1983, 48,5280 .

5. Only activated bromides such as allylic and benzylic bromides react readily with zinc: (a) Gaudemar, M. Bull. Soc. Chim. Fr. 1962, 974; (b) Berk, S.C.; Knochel, P.; Yeh, M.C.P. J. Org. Chem. 1988, 53, 5789; (c) Berk, S.C.; Yeh, M.C.P.; Jeong, N.; Knochel, P. Organometallics 1990, 9, 3053; (d) Retherford, C.; Chou, T.-S.; Schelkun, R.M.; Knochel, P. Tetrahedron Lett. 1990, 31, 1833; (e) Knochel, P. J. Am. Chem. Soc. 1990, 112,7431 .

6. For a review on the preparation of $\alpha$-chloroalkyl phenyl sulfides: Dilworth, B.M.; McKervey, M.A. Tetrahedron 1986, 42, 3731.

7. The preparation of the corresponding lithiomethyl thioester can be prepared by direct deprotonation using a hindered lithium amide. Deprotonation of more hindered thioesters or thiocarbamates is also possible: (a) Beak, P.; McKinnie, B.G.; Reitz, D.B. Tetrahedron Lett. 1977, 1839; (b) Beak, P.; Becker, P.D. J. Org. Chem. 1982, 47, 3855; (c) Beak, P.; Reitz, D.B. Chem. Rev. 1978, 78, 275; (d) Seebach, D.; Lubosch, W. Ang. Chem. Int. Ed. Engl. 1976, 15, 313;

8. Knochel, P.; Yeh, M.C.P.; Berk, S.C.; Talbert, J. J. Org. Chem. 1988, 53, 2390.

9. For the reaction of the zinc-copper reagents $\mathrm{RCu}(\mathrm{CN}) \mathrm{ZnX}$ with various classes of electrophiles see (a) Yeh, M.C.P.; Knochel, P.; Santa, L.E. Tetrahedron Lett. 1988, 29, 3887; (b) Yeh, M.C.P.; Knochel, P.; Butler, W.M.; Berk, S.C. Tetrahedron Lett. 1988, 29, 6693; (c) Yeh, M.C.P.; Knochel, P. Tetrahedron Lett. 1989, 30, 4799; (d) Majid, 
T.N.; Yeh, M.C.P.; Knochel, P. Tetrahedron Lett. 1989, 30, 5069; (e) Retherford, C.; Yeh, M.C.P.; Schipor, I.; Chen, H.-G.; Knochel, P. J. Org. Chem. 1989, 54, 5200; (f) Majid, T.N.; Knochel, P. Tetrahedron Lett. 1990, 31, 4413.

10. (a) Knochel, P.; Seebach, D. Tetrahedron Lett. 1982, 23, 3897; (b) Seebach, D.; Calderari, G.; Knochel, P. Tetrahedron 1985, 41, 4861

11. Chen, H.-G.; Gage, J.L.; Barrett, S.D.; Knochel, P. Tetrahedron Lett. 1990, 31, 1829.

12. Alpha-iodosulfides generated in situ have been found to insert chromium(II) chloride affording ( $\alpha$-thioalkyl)chromium(III) reagents: Nakatsukasa, S.; Takai, K.; Utimoto, K. $J$. Org. Chem. 1986, $51,5045$.

13. (a) Baldwin, J.E. J. Chem. Soc., Chem. Commun. 1976, 734; (b) Baldwin, J.E.; Cutting, J.; Dupont. W.; Kruse, L.; Silberman, L.; Thomas, R.C. I. Chem. Soc. Chem. Commun. 1976, 736; for some examples of 5- or 6-Endo-Trig ring closures, see: (c) Ellis, G.W.L.; Tavares, D.F.; Rauk, A. Can. J. Chem. 1985, 63, 3510; (d) Iwata, C.; Hattori, K.; Uchida, S.; Imanishi, T. Tetrahedron Lett. 1984, 25, 2995; (e) Mashraqui, S.H.; Kellogg, R.M. Tetrahedron Lett. 1985, 26, 1457; (f) Carretero, J.C.; Garcia Ruano, J.L.; Rodriguez, J.H. Tetrahedron Lett. 1984, 25, 3029; (g) Auvray, P.; Knochel, P.; Normant, J.F. Tetrahedron Lett. 1985, 26, 4455; (h) Corey, E.J.; Su, W.; Houpis, I.N. Tetrahedron Lett. 1986, 27, 5951.

14. (a) Chuit, C.; Foulon, J.P.; Normant, J.F. Tetrahedron 1981, 37, 1385; 1980, 36, 2305; (b) Bourgain-Commerçon, M.; Foulon, J.P.; Normant, J.F. Organomet. Chem. 1982, 228, 321; (c) Corey, E.J.; Boaz, N.W. Tetrahedron Lett. 1985, 26, 6015, 6019; (d) Horiguchi, Y.; Matsuzawa, S.; Nakamura, E.; Kuwajima, I. Tetrahedron Lett. 1986, 27 , 4025; (e) Nakamura, E.; Matsuzawa, S.; Horiguchi, Y.; Kuwajima, I. Tetrahedron Lett. 1986, $27,4029$.

15. Piers, E.; Nagakura, I. Synth. Comm. 1975, 5, 193.

16. Yeh, M.C.P.; Knochel, P. Tetrahedron Lett. 1988, 29, 2395.

17. (a) Knochel, P.; Normant, J.F. Tetrahedron Lett. 1985, 26, 425; (b) Auvray, P.; Knochel, P.; Normant, J.F. Tetrahedron Lett. 1985, 26, 2329.

18. Villieras, J.; Rambaud, M. Synthesis 1982, 924.

19. Cronin, J.P.; McKesvey, M.A., unpublished results; see ref. 6.

20. Trost, B.M.; Keeley, D.E.; Amdt, H.C.; Rigby, J.H.; Bogdanowizs, M.J. J. Am. Chem. Soc. $1977,99,3080$.

21. Hurd, C.D.; Gershbein, L.L. J. Am. Chem. Soc, 1947, 69, 2328.

22. Tamura, Y.; Ikeda, H.; Mukai, C.; Morita, I.; Ikeda, M. J. Org. Chem. 1981, 46, 1732. 